\title{
U) economics
}

B

Strategic investment decisions under the nuclear power debate in Belgium

Julia de Frutos Cachorro

Gwen Willeghems

Jeroen Buysse 


\title{
Strategic investment decisions under the nuclear power debate in Belgium
}

\begin{abstract}
In view of the current nuclear power debate in Belgium, we analyze how uncertainty about a nuclear phase-out, coupled with the implementation of renewable energy subsidies and nuclear taxes, affects investment capacity and productivity decisions by Belgian electricity suppliers. To achieve this goal, considering the key characteristics of the Belgian market, we build a Stackelberg closed-loop (two-stage) equilibrium model in which investment decisions are made in a first stage under uncertainty regarding a nuclear phase-out, and productivity decisions are subsequently made in a second stage in a certainty environment. Our analysis indicates that, regardless of subsidies, an increase in the probability of nuclear license extension results in lower levels of investment - primarily in renewable energy -, lower total production and a higher electricity price. We also show that the implementation of renewable energy subsidies reduces the effect of an increase in probability of nuclear license extension on producer's decisions regarding expanded capacity and on total profits in the market.
\end{abstract}

JEL Codes: C72, L10, L94, Q40, Q48.

Keywords: Electricity market, capacity investment decisions, stackelberg-based model, closed-loop, uncertainty nuclear production, renewable energy subsidies.

Julia de Frutos Cachorro

Universitat de Barcelona

Gwen Willeghems

VITO - EnergyVille

Jeroen Buysse

Ghent University

Acknowledgements: This work has been funded by Belgian Science Policy Office Belspo, in the framework of the Belgian research action through interdisciplinary networks BRAIN-be, under the 'Assessment of Low carbon society Policy Instruments (ALPI)' project, grant number BR/143/A5/ALPI.. 


\section{Introduction}

The Belgian electricity market is characterized by high dependence on nuclear energy and a dominant market position by one of the market players that operates all the nuclear plants in Belgium. Since 2003, the Belgian government seems committed to a nuclear phase-out. However, recently, the government extended the operational license permits of the three oldest nuclear power plant units from 2015 to 2025 because of a highly likely shortage of electricity supply. In view of this uncertainty regarding a nuclear phase-out and the EU's Renewable Energy Directive, ensuring security of supply and a stable investment climate has become an important challenge for decision makers. The goal of this study is to analyze how uncertainty about a nuclear phase-out, coupled with the implementation of renewable energy subsidies and nuclear taxes, affects the investment capacity and productivity decisions of electricity suppliers in Belgium.

In this context, a number of studies have already been conducted on the future of Belgian power generation and the optimal electricity mix (see Albrecht and Laleman (2014), Van Wortswinkel and Lodewijks (2012)). Van Wortswinkel and Lodewijks (2012) applied the Belgian TIMES model, which is a techno-economic, partial equilibrium model of the energy system, to the case of the Belgian region of Flanders, with the purpose of supporting the model user in their decision-making on cost-optimal energy. Through a model similar to the PRIMES ${ }^{1}$ model, Albrecht and Laleman (2014) investigated policy trade-offs for the Belgian electricity system and concluded that (i) market participation by renewables is essential for an affordable and sustainable energy mix in the future, (ii) a higher share of renewables will result in higher overall system costs in future decades, and (iii) the feedstock costs of biomass will be the main driver in the overall costs of any energy mix involving a high share of renewable energy (RE) technologies.

Indeed, most of the economic literature about electricity market structure and production decisions is based on partial and general equilibrium models (Albrecht and Laleman, 2014; Van Wortswinkel and Lodewijks, 2012), in which the main model assumption is that individual suppliers of the electricity market assume

\footnotetext{
${ }^{1}$ The PRIMES energy model simulates the European energy system through a multi-market equilibrium solution for energy supply and demand (Capros, 1998).
} 
perfect competition; that is, they consider that no single firm can influence the market price. However, in reality, proper market models must deal with imperfectly competitive markets (see Ventosa et al., 2005 for a review), that is, suppliers can take a strategic position to influence the market price and, thereby, the total electricity generation capacity in the market. As explained above, the Belgian electricity market is characterized by a dominant firm that accounts with the $60 \%$ of the installed capacity, including all nuclear plants. Thus, we could assume that only the dominant firm has market power. In order to take into account this fact within the modelling, we have developed an stackelberg-based model in which there is one leader firm, who is the first to take decisions, and one follower, who chooses subsequently. Both leader and follower compete in quantities.To the best of our knowledge, this equilibrium concept has not so far been introduced in the current models of electricity mix forecast for the Belgian case.

Moreover, as described in the first paragraph, we consider important characteristics of the Belgian context, such as policy uncertainty regarding nuclear phase-out. Indeed, the vast majority of the previous papers considers uncertainty on demand and prices, as the main sources of uncertainty on electricity markets, while policy uncertainty is often neglected. Centeno et al. (2003) pointed out the difficulties of accounting for uncertainty in large scale problems. In this paper, we focus on the uncertainty about a nuclear phase-out and how this uncertainty influences new investments in clean technologies in the Belgian market. In particular, production and additional investment capacity strategies in equilibrium are analyzed in a two-stage closedloop model. In fact, closed-loop models are more suitable to represent the real decision process in the electricity market, as argued by Wogrin et al. (2013). In our study, in a first stage, firms decide about their investment capacity decisions under different probabilities of nuclear license extension, and, subsequently, in a second stage, firms decide about their yearly production hours, in an environment with certainty about their current installed capacities, i.e., taking into account the results of the first stage. We show that lower production amounts and higher prices are reached in a certainty environment in which the extension of nuclear permits is guaranteed as compared to the case of a definitive nuclear phase-out. Moreover, new investments in renewables increase when the probability of nuclear license extension decreases, reaching 
the maximum levels in case of certainty about a nuclear phase-out. Finally, we analyze these previous results, with and without considering the implementation of renewable subsidies and nuclear taxes. We show that the presence of renewable energy subsidies plays a fundamental role in the overall entirety of electricity mix and strategic positioning of electricity producers.

The paper is organized as follows. Section 2 presents an overview of the Belgian context, including the specific nuclear policy framework, as well as power market characteristics and related literature. In Section 3, we describe the model, followed by an explanation of model parameters and assumptions in Section 4 . Model results are presented in Section 5, and, finally, the paper is concluded and discussed in Section 6.

\section{The Belgian context: Nuclear policy framework, power market characteristics and related literature}

\subsection{Legislative framework about nuclear phase out}

Belgium currently has seven nuclear reactors, the first of which became operational in 1974. Engie Electrabel operates all seven nuclear units and owns three of the units outright, as well as $89.8 \%$ of another three (the remaining $10.2 \%$ are owned by EDF Luminus). Electrabel jointly owns the remaining unit with France's EDF.

On 31 January 2003, the Belgian Senate approved the Federal Act which prohibited the building of new nuclear power plants and limited the operating lives of existing ones to 40 years, effectively shutting down 30\% of the country's nuclear capacity in 2015 (Belgian Federal Government, 2003; International Energy Agency, 2016; World Nuclear Association, 2016). In 2007, however, the Commission on Energy 2030, in its final report, advised keeping the nuclear option open and reconsidering the nuclear phase-out as it would be extremely expensive and greatly unsettling for the economy under post-Kyoto constraints and in the absence of Carbon Capture and Storage (D'haeseleer et al., 2007). This advice was repeated two years later in the government-commissioned report from GEMIX on the ideal energy mix for Belgium (Groep GEMIX, 2009). Moreover, the same Commission on Energy 2030 report defined four priorities to guarantee security 
of supply, the following two of which are the most relevant in the framework of this study. Firstly, the Commission identified diversity of supply of primary sources and technologies (type and origin) as a first and foremost rule. Secondly, they stated that a stable investment climate must be guaranteed for competitive market players to have timely and sufficient new electricity generation capacity and to retain a substantial refinery capacity (D'haeseleer et al., 2007), a recommendation that was reiterated in the GEMIX report (Groep GEMIX, 2009).

In 2009, based on the GEMIX report, the Belgian government decided to postpone the phase-out of the oldest reactors by 10 years, until 2025. However, new elections took place in 2010 before the postponement was passed by Parliament and the phase-out remained in place as originally planned, i.e. for 2015 .

In December 2011, the government confirmed that it would close the nuclear power plants in accordance with the phase-out law of 2003. At the same time, wholesale prices were too low and policy uncertainty too high to trigger investments in other baseload capacity (International Energy Agency, 2016). This coincided with the unforeseen long outages at two units from mid-2012 onwards due to the detection of thousands of quasi-laminar flaws in the forged rings of the reactor vessels (FANC, 2015). As security of supply came under heavy pressure, the government, with the approval of the Nuclear Safety Authority, extended the long-term operation of the three oldest nuclear power plant units from 2015 to 2025 , in combination with a number of other measures (International Energy Agency, 2016).

However, the extension to the operational license for these three nuclear plants has not solved the issue of security of supply. It has merely postponed it to 2022-25 when the remaining four plants will be shut down, as foreseen under the current policy. The International Energy Agency recommends that the government seriously consider what would be the optimal policy for securing affordable low-carbon electricity. It suggests that allowing the nuclear plants to run for as long as they are considered safe by the regulator would ease pressure on security of electricity supply. The extension of the nuclear license would also reduce the costs of electricity generation in the medium term and likely reduce the costs of the phase-out itself (International Energy Agency, 2016). This recommendation is in line with the recommendation formulated 
in the European Commission's Energy Road Map 2050 (European Commission, 2012) which states that nuclear energy will be required to provide a significant contribution to the energy transformation process in those Member States where it is pursued, as it remains a key source of low carbon electricity generation. In the meantime, the uncertainty about the nuclear phase-out still does not create a stable investment climate for competitive market players to diversify the primary power generation sources. In August 2017, the Federation of Enterprises in Belgium advocated more realism about the timing to close all nuclear plants (Belga, 2017a). And in October 2017, Belga (Belga, 2017b) reported that the current draft of the Energy Pact, the energy consultation between the Federal government and the regions, does not make mention anywhere about the feasibility of the nuclear phase-out. As the issue of the nuclear phase-out keeps reappearing in the news on a regular basis, this indicates the importance of our research topic.

In this context, we will analyze how investment capacity decisions by electricity suppliers in Belgium are influenced by an increase in the probability of extending the nuclear license, and how these results are affected by the implementation of environmental energy policies, such as nuclear tax or renewable subsidies. In what follows, we briefly describe the background of nuclear taxes and subsidies for renewables in Belgium.

\subsubsection{Nuclear Taxes}

Two types of nuclear tax exist in Belgium, i.e. the annual fee and the nuclear tax.

The annual fee is levied as the counterpart of the extension of the nuclear license and was established under the Federal Act of 31 January 2003, where it was decided that the operators of the three oldest nuclear plants should pay an annual fee. This fee is allocated to the 'Energy Transition Fund' and amounts to $€ 20$ million per year per reactor (Belgian Federal Government, 2003; JVH, 2016).

The nuclear tax is a repartition contribution levied by the Belgian Federal Government since 2008 for nuclear plant operators, targeting the four newest nuclear plants. The contribution is calculated based on the capacity of the installations and changes annually as a function of the profits generated by electricity 
production through nuclear fission. Contrary to the annual fee, this contribution is mainly aimed at funding the State's energy policy - it is allocated to the General State Budget - and at increasing competition on the electricity market. The repartition contribution amounted to $€ 200$ million in 2015 (Synatom, 2016).

\subsubsection{Renewable Energy Subsidies}

Tax and non-tax incentives in favor of renewables (RE) have been introduced both at the federal level and at the regional level. On the one hand, the Federal government has adopted different tax incentives, such as tax credit for research and development and green investment tax deduction. On the other hand, the three regions in the country have introduced a wide range of non-tax incentives, ranging from support systems for research and development, ecology and energy premiums, to a system of green certificates, allowing producers of RE sources to receive a complementary price for their sales of RE (CREG, 2010). The system works on the basis of green energy quotas, which transmission system operators are required to purchase. The price of the certificates is determined by the market, but a minimum price is guaranteed (Belgian Federal Government, 2002; Flemish Government, 2009).

Once our research question is justified, in the following section, we will describe the market power characteristics of the Belgian Electricity market, the related literature to market power and uncertainty in oligopolistic models, as well as the implication of both in the structure of the model, which is described in section 3 .

\subsection{Market power characteristics}

As is the case for most of the electricity industry in Europe, the Belgian electricity market is vertically unbundled. Transmission and distribution of electric power are regulated natural monopolies. Electricity generators and electricity suppliers operate in a liberalized market environment. Currently, the electricity market is an energy-only market (KU Leuven Energy Institute, 2015). The wholesale market consists of an Over The Counter (OTC) market and the spot market, which is made up of the Belpex Day-Ahead Market 
(DAM) and the Belpex Continuous Intraday Market (CIM) (Liebl, 2013). According to the KU Leuven Energy Institute (2015), in 2013, the total traded volume on the Belpex DAM amounted to 17.1 TWh, or $21 \%$ of the Elia ${ }^{2}$ grid load, and a total of about 0.6 TWh was traded on the Belpex CIM, or $1.5 \%$ of the Elia grid load. Even though the majority of the traded electricity volume is settled through OTC contracts, the DAM is of fundamental importance as a benchmark and reference point for other markets, such as OTC or forward markets (Grimm et al., 2008). Therefore, we model the capacity and production decisions of the electricity market through a closed-loop, two stage game, as suggested by Murphy and Smeers (2005) and other authors, using Belpex DAM data.

Moreover, the Belgian electricity market is characterized by two specific features that have a substantial influence on the functioning of the market. These are presented in Table 1.

<< insert Table 1: Overview of Belgium's existing power generation structure (Elia, 2016a) >>

First of all, there is a high dependence on nuclear energy, with this technology being responsible for over $30 \%$ of the current total installed power generation capacity. The second biggest technology is the closed cycle gas turbine (CCGT), which accounts for almost $24 \%$ of the total installed capacity, followed by solar photovoltaic (PV) at 15\%. Secondly, one player, i.e. Engie Electrabel, holds a dominant market position with more than $58 \%$ of this current capacity, including the nuclear reactors. None of the other market players hold a share of more than $5 \%$ of the total installed capacity. From this context, we could derive and assume that this is the typical situation of imperfect competition oligopolistic market in which only the dominant player has market power. Moreover, we could also assume that remaining small firms act as one player (the follower), such as price takers. A survey of the related literature of oligopolistic markets and market power is then needed in order to develop the design of our model. This is described in the following section.

\subsubsection{Literature related to oligopolistic market models and market power}

\footnotetext{
${ }^{2}$ Elia is Belgium's high-voltage transmission system operator ( $30 \mathrm{kV}$ to $380 \mathrm{kV}$ ), operating over $8000 \mathrm{~km}$ of lines and underground cables throughout Belgium.
} 
Most of the papers dealing with decision-making in imperfect competition oligopolistic markets, which is the most common situation, have developed Nash-equilibrium models (see Ventosa et al., 2005 for a review). This is a concept of game theory in which players (in this case, electricity suppliers) choose their optimal decision strategies based on the strategies of all the other players. Thus, players are in Nash equilibrium when each firm's strategy is the best response to the strategies employed by the other players.

In particular, the formulation of our electricity market model as a Nash-equilibrium game is based on production (e.g. Leibowicz, 2015) and investment capacity decision models (e.g Filomena et al., 2014; Genc and Sen, 2008; Murphy and Smeers, 2005) from the existing literature. We can mainly distinguish between open-loop (e.g. Leibowicz, 2015), one-stage decision games, and closed-loop games (e.g Filomena et al., 2014), two-stage or multi-stage decision games. Leibowicz (2015) couples a regional integrated assessment model and a one-shot (open-loop) Nash-equilibrium model to investigate how climate policy and learning spillovers interact with market electricity structure to affect production decisisions, and more specifically, renewable technology adoption and producer profits. Filomena et al. (2014) analyze the problem of production decisions, technology selection and capacity investment for electricity generation in a competitive environment under uncertainty concerning marginal costs, by using a closed-loop game, in which investment decisions are made in a first stage under uncertainty and productions decisions are made in a second step, when the marginal cost is fixed.

Another possible classification among Nash-equilibrium models depends basically on the type and scope of decisions, and market power of the different agents. On one hand, Nash-Cournot models are more easy to represent and are suitable for markets in which it is assumed that all players have market power, and then, take decisions simultaneously. Stackelberg-based models, on the other hand, consider that one (Mathematical Program with Equilibrium Constraints (MPEC) models, e.g. Ventosa et al., 2002; Gabriel and Leuthold, 2010) or several agents (Equilibrium Program with Equilibrium Constraints (EPEC) models, e.g. Murphy and Smeers, 2005) can act as leaders of the market and then take decisions in a first place. Remaining firms (followers) take decisions subsequently in a Cournot manner. Murphy and Smeers (2005) 
compare long-term investment in generation capacity under different market electricity structures, namely perfect competition and oligopolistic markets, with dynamic interactions (open-loop and closed-loop Nash equilibria). The closed-loop equilibrium is a two-stage decision game, where the first stage is solved by an EPEC model. Ventosa et al. (2002) analyze expansion planning under imperfect competitive conditions, by using an MPEC approach, where the leader firm decides its optimal new capacity, subject to a set of market equilibrium constraints.

Finally, we can distinguish between static and dynamic models, which consider dynamic interactions between players. In fact, most of the papers that analyze investment strategic decisions in competitive markets advocate for the use of dynamic multi-period models (e.g Genc and Sen, 2008, Murphy and Smeers, 2005). Genc and Sen (2008) focus on investment capacity decisions in the electricity market in Ontario (Canada), by using the concept of S-adapted open-loop Nash equilibrium, a multi-period dynamic game with an uncertain demand price function. However, in these papers, authors have to make strong modelling assumptions due to the complexity of finding analytical solutions. For example, they consider a reduced number of technologies and/or periods, and players are typically assumed to be symmetric in the market. As a result, although their findings are sound from a theoretical perspective, they have limits in terms of its application to specific study cases.

In this paper, we simplify this theoretical literature by considering a closed-loop two-stage game of production and investment capacity decisions, but which takes into account all the producers and technologies on the Belgian market. Due to the characteristic of the Belgian market, that is, one leader firm (Electrabel) and one follower (remaining firms), we also assume a Stackelberg-based model with MPEC structure in both decision stages. Moreover, in order to deal with our research question concerning decisionmaking under nuclear policy uncertainty, we assume that investment decisions in the first stage are made under uncertainty. In this context, in the next sextion, we briefly review the existing literature of uncertainty in oligopolistic market models. 


\subsubsection{Literature related to uncertainty in oligopolistic market models}

Indeed, the vast majority of oligopolistic market models considers uncertainty on economic parameters such as demand (e.g Genc and Sen, 2008; Murphy and Smeers, 2005), prices (e.g. Schröder, 2014), or marginal costs (e.g. Filomena et al., 2014) as the main sources of uncertainty on electricity markets. For example, Schröder (2014) pointed out the importance of considering long-term uncertainty, in this case uncertainty about fuel and carbon prices, on the analysis of investment decisions.

However, little attention is paid to instability of investments caused by policy uncertainty, in particular uncertainty about the future of nuclear power. Recent studies have analyzed the impact of the German nuclear phase-out on Europe's electricity generation and electricity prices. On the one hand, Bruninx et al. (2013) estimate that nuclear generation will be replaced by coal generation, leading to an increase in $\mathrm{CO}_{2}$ emissions. They hence argue for an extension of some nuclear plants' licenses. On the other hand, Nestle (2012) calls into question the reasons of the German government decision concerning nuclear plants' license extension and the expected increase on overall prices in a context of nuclear phase-out. However, in these papers, uncertainty about the nuclear phase-out policy is not explicitly considered.

The contribution of our paper consists of the analysis of how this uncertainty influences new investments in clean technologies in the Belgian market. Uncertainty is introduced in the first stage of our model, when taking investment decision. In particular, investment capacity decisions are made until different probabilities of nuclear license extension scenarios. Expansion outputs are subsequently introduced in the second stage of the model. In what follows, we present and describe in details the modelling approach.

\section{The Model}

The model starts from the assumption that a finite number $N$ of firms have a finite number of technologies $H$ at their disposal and have to optimally decide about their additional investment capacity possibilities 
$E_{i}(k)^{3}$ and their annual number of production hours, $P h_{i}(k)$, per firm $i$ and per technology $k$. These are chosen through a two-stage model in which, in a first stage, expansion capacities are decided under uncertainty about the extension of nuclear license permits. Subsequently, expansion capacities are injected in the second stage of the model and the annual number of production hours are decided in a certainty environment, for a given demand-price function. Moreover, as explained in the previous sections, due to the characteristics of the electricity market in the study area, we will assume an Stackelberg-based model for each stage, in which there is a leader firm (L) that decides its optimal decision, and a follower ${ }^{4}(\mathrm{~F})$ that makes its optimal decision, knowing the capacity (in the first stage) and the production hours (in the second stage) of the leader. A summary of the flow of decisions in the model is illustrated in $<<$ insert Figure 1 . A detailed description of the two-stage model is explained in the following sections.

\section{$<<$ insert Figure 1: Decision process of the model $>>$}

\subsection{First stage: Expansion capacity decisions}

\subsubsection{Model description}

In a first stage, firms aim to decide about their expansion in installed capacities, $E_{i}(k)$, which maximize their expected individual profit $\widehat{E}\left(\pi_{i}\right)$ (in $€$ ), where $\pi_{i}$ is defined as a discrete random variable that takes the value $\pi_{i}^{1}$ with probability $\gamma$ (given) if license permits for nuclear power plants are extended, and $\pi_{i}^{2}$ with probability $(1-\gamma)$ if not.

\footnotetext{
${ }^{3}$ We acknowledge that a firm can invest in a new technology that is part of the Belgian portfolio of technologies (see Table 1), even if it does not have any installations on it previously.

${ }^{4}$ In order to simplify our Stackelberg-based model and due to the specific characteristics of the study area, the remaining firms have been merged in one actor ( $\mathrm{F}$, the follower). We acknowledge that in a Stackelberg-based model, followers decide in a Nash-Cournot competition model (or a Nash-Cournot game) in which a finite number of noncooperative firms maximize their profits, taking into account the decisions of the other firms, (see Genc and Sen, 2008; Leibowicz, 2015). A Nash equilibrium for this game exists and can be derived from the optimality conditions of the model for each individual player.
} 
Let $\mathrm{I}=\{\mathrm{L}, \mathrm{F}\}$ denote the set of firms in the market, $\mathrm{K}=\{1 . . \mathrm{H}\}$ denote the set of available technologies and $\mathrm{S}=\{1,2\}$, the set of probability scenarios concerning the extension of nuclear license permits,

$\widehat{E}\left(\pi_{i}\right)=\gamma * \pi_{i}^{1}+(1-\gamma) * \pi_{i}^{2}, \quad \forall i \in I, \forall k \in K$,

with

$\pi_{i}^{S}=\sum_{k} \pi_{i}^{S}(k), \quad \forall i \in I, \forall k \in K, \forall s \in S$.

and $\pi_{i}^{S}(k)$, the individual profit per probability scenario per technology.

Firstly, $\pi_{i}^{S}(k)$ is described in equation (3) as the difference between the individual total income $T I_{i}^{S}(k)$ and the individual total $\operatorname{cost} T C_{i}^{S}(k)$ per technology, per probability scenario,

$\pi_{i}^{S}(k)=T I_{i}^{S}(k)-T C_{i}^{S}(k), \quad \forall i \in I, \forall k \in K, \forall s \in S$.

If we describe the previous equation in detail,

$T I_{i}^{S}(k)=Q_{i}^{S}(k) *\left(p^{s}+\operatorname{subs}(\mathrm{k})\right), \quad \forall i \in I, \forall k \in K, \forall s \in S$,

where $Q_{i}^{S}(k)$ is the quantity of electricity produced (in MWh) (equation (5)), $p^{S}$ is the electricity price (in $€ / \mathrm{MWh}$ ) (equation (7)), and subs(k) are subsidies received per technology (in $€ / \mathrm{MWh}$ ). In particular, we assume $\operatorname{subs}(\mathrm{k})>0$ for renewable technologies and $\operatorname{subs}(\mathrm{k})=0$ for the others.

Moreover, the individual amount of electricity produced per technology, for each probability scenario $s$, is the product of the annual quantity of production hours $P h_{i}(k)$ (in hours/year) and the final installed capacity, $F I C_{i}^{S}(k)$, which is described in equation (6) as the sum of the current installed capacity $I_{i}^{S}(k)$ (in MW), and the additional investment in capacity per firm and technology, $E_{i}(k)$ (in $\mathrm{MW}$ ),

$Q_{i}^{S}(k)=P h_{i}(k) * F I C_{i}^{S}(k)$,

$F I C_{i}^{S}(k)=I_{i}^{S}(k)+E_{i}(k)$,

$\forall i \in I, \forall k \in K, \forall s \in S$ 
Note that, in order to distinguish the different probability scenarios $s$, we consider $I_{i}^{1}$ (nuclear) $>0$ and $I_{i}^{2}($ nuclear $)=0$.

Next, the electricity price $p^{S}$ depends linearly on demand (see equation (7)), where coefficients $a$ and $b$ will be estimated later (see section 4.3) by linear regression,

$p^{s}=\mathrm{a}-\mathrm{b} * \sum_{i, k} Q_{i}^{S}(k), \quad \forall i \in I, \forall k \in K, \forall s \in S$.

Finally, as described in equation (8), the individual total cost, per technology and probability scenario, $T C_{i}^{S}(k)$, is made up of four components. The first component corresponds to the variable cost depending on the amount of electricity produced per technology, in particular, the sum of $V C(k)$, and feedstock costs, $F S C(k)$ (both in $€ / \mathrm{MWh}$ ). The variable cost includes variable operational and maintenance costs. It is a production-related cost which varies with electrical generation/consumption, and excludes personnel, fuel and $\mathrm{CO}_{2}$ emission costs. The second component corresponds to fixed operational and maintenance costs (excluding personnel and refurbishment costs) per technology $F C(k)$ (in $€ / \mathrm{MW}$ ), which depend on final installed capacity $F I C_{i}^{S}(k)$ (in MW). The third component consists of the capital expenditure, or investment cost, which is defined as a quadratic cost function with respect to additional investment capacity, $E_{i}(k)$ (in MW) with $C C(k)$, the unitary marginal investment cost per technology $\left(€ / \mathrm{MW}^{2}\right)$. Finally, the last component consists of the tax $t(k)$, in this case only applicable to nuclear energy and solely dependent on whether or not the technology is being used.

$T C_{i}^{S}(k)=(\mathrm{VC}(\mathrm{k})+\mathrm{FSC}(\mathrm{k})) * Q_{i}^{S}(k)+\mathrm{FC}(\mathrm{k}) * F I C_{i}^{S}(k)+\mathrm{CC}(\mathrm{k}) * \frac{E_{i}^{2}(k)}{2}+\mathrm{t}(k)$, $\forall i \in I, \forall k \in K, \forall s \in S$. 


\subsubsection{Model resolution}

As explained above, the first stage of the game is also a two-stage game in itself, in the sense that the leader firm choses first about its expansion capacity per technology, $E_{L}(k)$, and the follower choses subsequently about its expansion capacity per technology, $E_{F}(k)$, knowing the decision of the leader.

We firstly formulate the first-order optimality conditions, also known as the Karush-Kuhn-Tucker (KKT) conditions, of the follower problem in the first stage. These are the derivatives of the follower firm's objective functions $\hat{E}\left(\pi_{F}\right)$ with respect to decision variables $E_{F}(k)$ and will be used as a constraint of the "Leader" main optimization problem.

The first stage KKT conditions are then:

$\frac{\delta \hat{E}\left(\pi_{F}\right)}{\delta E_{F}(k)}=\gamma \frac{\delta \pi_{F}^{1}}{\delta E_{F}(k)}+(1-\gamma) \frac{\delta \pi_{F}^{2}}{\delta E_{F}(k)}=0 \quad \forall k \in K$,

with,

$\frac{\delta \pi_{F}^{S}}{\delta E_{F}(k)}=\frac{\delta Q_{F}^{S}(k)}{\delta E_{F}(k)} *\left(p^{S}+\operatorname{subs}(\mathrm{k})\right)+\frac{\delta p^{s}}{\delta E_{F}(k)} * \sum_{k} Q_{F}^{S}(k)-\frac{\delta T C_{F}^{S}(k)}{\delta E_{F}(k)}$,

$\frac{\delta Q_{F}^{S}(k)}{\delta E_{F}(k)}=P h_{F}(k)$,

$\frac{\delta p^{s}}{\delta E_{F}(k)}=-\mathrm{b} * P h_{F}(k)$

and,

$\frac{\delta T C_{F}^{S}(k)}{\delta E_{F}(k)}=P h_{F}(k) *[\operatorname{VC}(k)+\mathrm{FSC}(k)]+\mathrm{FC}(k)+\mathrm{CC}(k) * E_{F}(k)$,

$\forall k \in K, \forall s \in S$ 
Next, the problem of the leader is solved by means of a non-linear, Mathematical Program with Equilibrium Constraints (MPEC) structure, executed in GAMS using the MPEC solver (GAMS Development Corporation, 2010),

We can formulate the "leader" problem as follows:

$$
\begin{gathered}
\max _{E_{i}(k)} \hat{E}\left(\pi_{L}\right) \\
\text { s.t }(1)-(8) \text { and }(9)-(13), \\
\sum_{i} E_{i}(k) \leq E_{\max }(k), \\
\forall i \in I, \quad \forall k \in K,
\end{gathered}
$$

where $E_{\max }(k)$ represent the parameter of the maximum amount of expansion capacity per technology.

\subsection{Second stage: Production hours decisions}

\subsubsection{Model description}

In a second stage, firms decide on the amount of production hours $P h_{i}(k)$ that maximize their individual profit $\pi_{i}$ (in $€$ ), by knowing their installed capacities, $F I C_{i}(k)$. More specifically, decisions are taken under a certainty environment in which the final installed capacities correspond to the current installed capacities of the current situation (probability scenario $\mathrm{s}=1$ ), $I_{i}^{1}$, that is, when nuclear installations are present, plus the given expansion capacities found in the first stage of the model, $E_{i}^{*}(k)$.

Thus,

$$
F I C_{i}(k)=I_{i}^{1}(k)+E_{i}^{*}(k), \quad \forall i \in I, \quad \forall k \in K
$$

Model parameters and model equations (2)-(8) on individual profit $\pi_{i}$, individual total income $T C I_{i}$, individual amount of electricity produced $Q_{i}$, final installed capacity $F I C_{i}$, price-demand function $p\left(Q_{i}\right)$, and individual total cost $T C_{i}$ per technology $k$, in the second stage are then, the sames than for the first 
stage of the model, but the only probability (or installed capacity scenario) considered is $\mathrm{s}=1$, avoiding then the probability scenario notation.

\subsubsection{Model resolution}

As in section 3.1.2, we first formulate the KKT conditions of the follower firm, which will be used as a constrant of the main "leader" problem in the second stage.

The second stage KKT conditions for the follower are the derivatives of $\pi_{F}$ with respect to the decision variable $P h_{F}(k)$ :

$\frac{\delta \pi_{F}}{\delta P h_{F}(k)}=\frac{\delta Q_{F}(k)}{\delta P h_{F}(k)} *(p+\operatorname{subs}(k))+\frac{\delta p}{\delta P h_{F}(k)} * \sum_{k} Q_{F}(k)-\frac{\delta T C_{F}(k)}{\delta P h_{F}(k)}$,

$\frac{\delta Q_{F}(k)}{\delta P h_{F}(k)}=F I C_{F}(k)$

$\frac{\delta p}{\delta P h_{F}(k)}=-\mathrm{b} * F I C_{F}(k)$

and,

$\frac{\delta T C_{F}(k)}{\delta P h_{F}(k)}=F I C_{F}(k) *[\operatorname{VC}(k)+\operatorname{FSC}(k)], \quad \forall k \in K$.

As in 3.1.2, we can formulate the "leader" problem as follows:

$$
\begin{gathered}
\max _{P h_{i}(k)} \pi_{L} \\
\text { s.t }(1)-(8) \text { and }(14)-(18) \\
P h_{i}(k) \leq P h_{\text {max }}(k), \\
\forall i \in I, \forall k \in K,
\end{gathered}
$$

where $P h_{\max }(k)$ represent the parameter of the maximum number (per year) of operating hours per technology. 


\section{Model Parameterization and assumptions}

\subsection{Technology assumptions}

The starting point of the model is the current capacity of the different technologies installed in Belgium for the leader firm and the follower firm (see Table 2). These data were obtained from Elia (Elia, 2016a).

Table 2 provides an overview of the most relevant economic parameter values, as well as assumptions made on maximum values of decision variables.

<< insert Table 2: Economic parameter values (left-hand side) and maximum values assumed for decision variables (right-hand side), per firm i and technology $k>>$

Data regarding capital investment costs $C C(k)^{5}$ and fixed and variable operational costs, $F C(k)$ and $V C(k)$ respectively, were taken from the ETRI Report (Joint Research Centre, 2014). Feedstock costs FSC ( $k$ ) were taken from Laleman et al. (2012) for all technologies except anaerobic digestion. For the latter technology, feedstock costs were calculated based on assumptions from a 2016 report by the Flemish Energy Agency VEA (Vlaams Energieagentschap, 2017).

The maximum amount of production hours per technology $P h_{\max }(k)$ was taken from Albrecht and Laleman (2014), while the maximum possible expansion capacity for all firms per technology $E_{\max }(k)$ was derived from a number of sources. First of all, the maximum capacity for offshore wind was taken from the Elia study on adequacy and flexibility in the Belgian electricity system (Elia, 2016b). Secondly, the maximum expansion capacity for onshore wind production for Belgium was calculated in the following way. The maximum wind production potential (European Wind Energy Association, 2005), being 5 TWh per year, was divided by the maximum amount of full load hours to determine the maximum capacity. The present installed capacity $\sum_{i} I_{i}^{S}(k)$ was then detracted from the maximum final capacity $\sum_{i} F I C_{i}^{S}(k)$, resulting in the maximum possible expansion capacity $E_{\max }(k)$, which was finally split into equal parts in order to obtain

\footnotetext{
${ }^{5}$ We assume that investment costs are amortized over 20 years.
} 
the maximum possible expansion capacity per firm. Similar calculations were conducted for solar PV technology. In this case, however, we estimated the maximum annual production by first calculating the potential for building integrated photovoltaics for Belgium (International Energy Agency, 2001), followed by the calculation of the energy produced each month by taking into account monthly solar irradiance and number of days per month. As described in the nuclear exit framework (see section 2.1), there will no further expansion of nuclear energy. Moreover, due to the commitments made by Europe to reduce $\mathrm{CO}_{2}$ emissions, we assume that there will be no expansion in the capacity of coal-fired power plants (Elia, 2016b). Equally, as Belgium has very limited potential to increase its hydro capacity, we assume that there will be no expansion in the capacity of this particular technology either (Albrecht and Laleman, 2014b). Finally, we assume that municipal solid waste incinerators are built with the objective of getting rid of the last nonrecyclable fraction of municipal waste and not with the objective of producing additional power. We therefore assume that the expansion in capacity of this particular technology will also be zero.

\subsection{Nuclear taxes and renewable energy subsidies}

Section 2.1.1 explains the details of the nuclear tax calculation. However, to reduce model complexity, we opted to use a lump sum of $€ 250$ million instead of a more complex calculation. This amount is the sum of nuclear taxes for all Belgian plants in 2008.

In order to keep computational calculations feasible for the model, subsidies for renewable energy (RE) were set at $€ 93$ per MWh produced for all RE technologies, except for municipal solid waste incineration. In Flanders, this is the minimum amount of support for all RE installations with a starting date of 1 January 2013 independent of the type of RE technology that is used. This amount of support was set in articles 7.1.6 and 7.1.7 of the Energy Decree (Flemish Government, 2009). For installations with a starting date before 1 January 2013 the system is much more complex (see VREG, n.d. for an overview). Municipal solid waste incinerators also receive subsidies in Flanders, as part of the waste is considered as a 'renewable' energy source. This fraction consists of food waste, badly sorted paper and cardboard, etc. As the waste is not considered to be $100 \%$ renewable, subsidies amount to $€ 60$ per MWh produced (Pauwels, 2016). As energy 
subsidies are regionalized (see section 2.1.2), a different system exists for the region of Wallonia and Brussels-capital (Elia, 2016c). However, to reduce model complexity we opted to use the Flemish approach for all power production.

\subsection{Electricity price demand function}

The electricity price is endogenously determined by the model through a linear demand-price function (see equation 7). This demand-price function is based on Belpex data regarding average electricity price on the day-ahead market (in €/MWh) (Belpex, 2016) from 2006 to 2014. We used day-ahead (spot) market data because, as previously mentioned in Section 2.2, according to Grimm et al. (2008), the DAM price is of fundamental importance as benchmark and reference point for other markets. For each year of data, we calculated the average hourly quantity of electricity produced (in MWh) as well as the average electricity price (in $€ / M W h$ ). We then conducted a linear regression using the statistical computing language $R$ ( $R$ Development Core Team, 2008), version 3.1.2, where coefficients $a$ and $b$ of equation (7) were determined:

$$
\begin{gathered}
a=49.74, \\
b=-0.001679 .
\end{gathered}
$$

Finally, as Belpex DAM data is available on an hourly basis and the simulations in our decision model are made on a yearly basis, we had to make the transition from years (calculated in the model) to hours (derived from the Belpex data) in the price demand function. Therefore, in the function, we divided the total quantity of electricity produced $\sum_{i, k} Q_{i}^{S}(k)$ by 8760 , i.e., the amount of hours in one year. The adapted function we use in the model simulations then becomes

$$
p^{s}=49.74-0.001679 * \sum_{i, k} Q_{i}^{S}(k) / 8760
$$




\subsection{Investment cost function}

We assume a quadratic investment cost function to capture increasing costs of additional investments which will stimulate firms to expand with multiple technologies, and to obtain more qualitative results (Genc and Sen, 2008; Genc and Zaccour, 2011). These increasing costs capture, for instance, the effect that the best locations to invest in technologies such as wind or solar PV are taken first at a lower cost. A higher capacity will require most costs to find more suitable places and make them available for the generation of power. In particular, the investment cost function per firm per technology is assumed to be convex and increasing with respect to investment capacity expansion $E_{i}(k)$, and has the following functional form:

$d(k) * E_{i}(k)+e(k) * \frac{E_{i}^{2}(k)}{2}$,

with $d(k)$ and $e(k)$ positive parameters.

Because we do not have sufficient data to regress investment expenses with respect to additional investment capacity, we attribute all investment expenses to the quadratic term ${ }^{6}$. Thus, we assume $d(k)=0$ and $e(k)=$ $C C(k)$, where $C C(k)$ is the marginal unit investment cost per technology and is taken from the ETRI Report (Joint Research Centre, 2014). As final results could be affected by this important assumption, a discussion of these parameter costs is provided in the scenario analysis in section 5.3.

\section{Results}

In this section, we analyze how an increase in the probability of extending the nuclear license, coupled with the implementation of renewable (RE) subsidies and nuclear taxes, influences investment capacity (first stage) and productivity (second stage) decisions by electricity suppliers in equilibrium. We first look at the effect of an increase in the probability of extending the nuclear license, or, equivalently, a decrease in the probability of nuclear phase-out, on additional installed capacities, production, prices and profits of Belgian electricity suppliers, taking into account RE subsidies and nuclear taxes. To this goal, simulated results are

${ }^{6}$ Other papers such as Genc and Thille (2011) argued that this type of convex investment cost function may stem from adjustment costs, which are due to costs of installing and/or removing equipment. 
shown for different predefined probabilities for extension of the nuclear license, in the absence and presence of taxes and RE subsidies respectively. The benchmark scenario calculates the Stackelberg equilibrium with nuclear tax and renewable (RE) subsidies, assuming that nuclear license permits will be extended $(\gamma=1)$. We also look at a high $(\gamma=0.75)$, medium $(\gamma=0.5)$, low $(\gamma=0.25)$, and nil $(\gamma=0)$ probability for extension, the latter corresponding to a probability scenario in which nuclear phase-out is guaranteed. Finally, we look at the effect of the implementation of RE subsidies and nuclear taxes, on simulated results, by comparing results without and with RE subsidies and nuclear taxes. Table 3 provides an overview of the main results. More detailed results can be found in the annexes.

\section{$<<$ insert Table 3: Overview of results for the different model scenarios $>>$}

\subsection{Effect of probability of extending the nuclear license}

To understand the effects of an increase in the probability of extending the nuclear license, we compare model results for different predefined probabilities $\gamma$ of extending the nuclear license for the case of RE subsidies and nuclear taxes, which corresponds to the current situation in Belgium (see rows 2-6 in Table $3)$.

First of all, we look at additional investments (or expansion) in installed capacity depending on the level of probability $\gamma$ (see column 3 of Table 3). We can see that lower probabilities of license extension result in higher investments in capacity. This is because, when the probability of extension is low, players expect that more non-nuclear capacity will be needed to fulfill demand and then, more investments take place. More specifically, Figure 2 shows how the leader and follower expand depending on the level of probability $\gamma$, (see also Annex 4 for detailed numbers).

$<<$ insert Figure 2: Expansion in capacity (in MW) in function of the level of probability of nuclear license extension $\gamma$ for the leader and follower $>>$ 
Again, a lower probability of extension corresponds to a higher level of expansions for both players. We can observe that, even if the follower has higher levels of capacity expansion as compared to the leader in order to be able to compete - and this for each level of $\gamma$-, the expansion by the leader is more influenced by an increase of probability. For example, when probability of nuclear license extensions increases from 0 (nuclear phase-out) to 1 (nuclear extension), expansion capacity increases by $1655 \mathrm{MW}$ for the leader and $568 \mathrm{MW}$ for the follower. The reason here for this is that, with decreasing probability for nuclear license extension, the leader, who owns all the nuclear capacity, is more inclined to further expand in order to compensate losses for the non-use of nuclear.

Next, $<<$ insert Figure 3 presents the portfolio of technologies that are used for the expansion, depending on the probability of nuclear license extension (see also Annex 3 for detailed numbers and Annex 2 for results per player).

\section{$<<$ insert Figure 3: Installed capacity expansion (in MW) per technology and probability level $\gamma$ $>$}

First of all, the figure shows that expansion takes place in renewable energy technologies only. Moreover, we can distinguish between two groups: those technologies that use biomass as feedstock (anaerobic digestion, biomass CHP cogeneration and biomass grate furnace steam turbines), and those technologies that do not use any feedstock, namely intermittent (i.e. non-flexible) renewables (i.e. offshore and onshore wind turbines and solar PV). Moreover, the figure indicates that the largest expansion takes place in two technologies, i.e. biomass grate furnace steam turbines and offshore wind for different reasons: offshore wind is a cheap technology in terms of $\mathrm{LCOE}^{7}$ costs (see LCOE calculations in Annex 7) and biomass grate furnace because of the absence of expansion limits, combined with the fact that it is the technology with the

\footnotetext{
${ }^{7}$ For details on technology costs, please refer to the specific LCOE calculations in Annex 4. We define the LCOE per technology, as the total costs divided by the total production per technology (in euros/MW). When we compare these values to the ones from other sources (Albrecht and Laleman, 2014b), we can see that they are in the same order of magnitude. Of course, due to the variable nature of the modeling, our LCOE values are lower as compared to the above-mentioned sources.
} 
lowest investment costs with respect to the other biomass based technologies (see Table 2). While, with increasing probability of nuclear extension, the expansion in capacity decreases for all technologies, the ratio with which this decrease happens is different for all technologies. Biomass-based technologies appear to be more influenced by a decrease in license extension probability than the others. For instance, the increase in expansion for anaerobic digestion from probability $\gamma=1$ to $\gamma=0$ is around $132 \%$ while it is only around $6 \%$ for solar PV. Onshore and offshore are the technologies that are the least influenced by a decrease in probability of license extension, because they are always expanded to the maximum capacity expansion limits.

Next, as can be observed in column 5 of $<<$ insert Table 3, total production decreases with increasing probability for license extension. As producing hours (see Annex 6) are not influenced by a change in probability, total production follows the same tendency as investments in capacity. For details regarding production per technology and probability level, we refer to Annex 8.

Moreover, as the total production decreases with increasing probability, prices $^{8}$ will increase with increasing probability of nuclear license extension (see Table 3, column 6). This means that the leader (Electrabel) places upward pressure on prices when a nuclear license is highly likely.

More specifically, in the total absence of nuclear power $(\gamma=0)$, electricity prices will decrease by around $8.5 \%{ }^{9}$ with respect to the baseline case, $(\gamma=1)$, in which the license extension is guaranteed, a statement that is in contradiction by numerous reports on the Belgian power sector (D'haeseleer et al., 2007; Febeliec, 2017; Groep GEMIX, 2009; International Energy Agency, 2016).

Finally, we can observe that total profits are non-monotonic with respect to the probability of license extension (see Table 3, column 4), and reach the highest value in the absence of uncertainty, that is when

\footnotetext{
${ }^{8}$ We acknowledge that electricity price is assumed to be a linear (with negative slope) function with respect to demand, as explained in section 4.3.

${ }^{9}$ Prices obtained in the scenario of total absence $(\gamma=0)$ and presence $(\gamma=1)$, of nuclear power for the case of RE subsidies and nuclear taxes are 26.897 and 29.39 euro/MWh, respectively.
} 
nuclear license extension or nuclear phase-out are guaranteed. Overall, total profits reach the maximum value for $\gamma=1$, which correspond to the scenario with the maximum simulated price. For profits per player, please refer to Annex 1 .

\subsection{Effect of renewable energy subsidies and nuclear tax}

Next, we analyze the effect of the implementation of RE subsidies and nuclear taxes on the firms' decisions, by comparing results with RE subsidies (see rows 2 and 6 in Table 3 ) and results without RE subsidies (see rows 7 and 11 in Table 3). The detailed numbers for this comparison can be found in the annexes.

As expected, the numbers in Table 3 show that the implementation of RE subsidies promotes investment in RE capacity. The total installed capacity increases almost eight-fold for each probability of nuclear license extension. The model also simulates a shift in choice of technologies driven by RE subsidies. This can be seen in Figure 4. Without RE subsidies (left-hand side of the figure), the model favors onshore wind over offshore wind and solar PV. When subsidies are provided, biomass-based technologies enter the electricity mix. These results are mainly driven by the capacity limit for onshore (i.e. $947 \mathrm{MW}$ in total) and offshore wind (i.e. $1588 \mathrm{MW}$ in total), and the quadratic investment cost function for all technologies. The RE subsidies stimulate both players to expand in RE technologies. They would do so preferably in the cheapest technology (see LCOE calculation in Annex 4) but, with increasing capacity, also the investment costs are simulated to increase (see section 4.4). The result is that the producers diversify their choice of technology when RE are provided.

\section{$<<$ insert Figure 4: Expanded installed capacity per technology in absence (left-hand side) and in case (right-hand side) of RE subsidies and nuclear taxes $>>$}

The above-mentioned results constitute a key element for decision-making in order to create a long-term stable investment strategy. Indeed, as stated in the existing literature, a very high share of intermittent (i.e. non-flexible) renewables (i.e. solar PV and wind) may reduce the security of the energy supply and grid stability and result in higher overall system costs (Albrecht and Laleman, 2014b; Szarka et al., 2013). Biomass-based conversion systems, on the other hand, while having high feedstock costs, offer technical 
alternatives for flexible power generation to compensate for fluctuations and the resulting residual load (Szarka et al., 2013). In our specific case, we see that the presence of subsidies increases the overall production share of biomass-based systems from around $7 \%$ to around $30-40 \%$ of the total production, depending on the probability scenario.

Overall, results follow the same patterns as in the previous section when the probability of nuclear license extension increases, but quantity levels are higher in the presence of RE subsidies and nuclear taxes. Thus, investment and total production decrease, while prices increase with increasing probabilities of nuclear extension. However, the presence of subsidies reduces the effect of the increase in probability, on total expansion capacity and, then, on total production. In particular, total expansion capacity decreases by $37 \%$, from $\gamma=0$ to $\gamma=1$, in absence of subsidies, and just by $21 \%$, from $\gamma=0$ to $\gamma=1$, that is, in presence of subsidies.

Finally, total profits are not greatly influenced by a change in the probability of nuclear license extension, and follow a different pattern in absence of RE subsidies and taxes as compared to the presence of RE subsidies and taxes. In the absence of subsidies and taxes, total profits slightly decrease (as does the total production) with increasing probability of license extension (see Table 3, column 4), in particular, decreasing of $0.8 \%$ from $\gamma=0$ to $\gamma=1$. In presence of subsidies and taxes, on the contrary, profits only slightly increase, by $0.1 \%$ from $\gamma=0$ to $\gamma=1$. Therefore, we can conclude that the implementation of subsidies and taxes slows down the effect of the increase in probability on total profits.

\subsection{Scenario analysis of quadratic investment cost function}

One important assumption of the model relates to the quadratic investment cost function (described in section 4.4). Because of the lack of data to estimate a quadratic cost function with respect to the additional investment capacity, we conducted a scenario analysis with different investment cost parameters in order to validate our choice which corresponds to the baseline case in Table 4. As can be seen in Table 4, we 
simulated four different scenarios, i.e. Baseline, Scenario 1a, Scenario 1b, Scenario 1c, in such a way that the marginal unitary cost per technology, $d(k)+e(k)$, is the same.

\section{$<<$ insert Table 4: Results of the different quadratic investment cost scenarios for each technology $>>$}

More specifically, simulation results regarding the optimal total additional investment capacity and expected profit are shown for the model probability scenario $\gamma=1$, our benchmark case. We don't observe important changes in total expansion capacities per quadratic cost scenario. Simulated investments are less than 5\% lower in the scenario 1c than in the baseline scenario. However, expected total profits are significantly different for the different quadratic cost function scenarios. In particular, we found the maximum value in the baseline case to be $€ 1829$ (in millions). Therefore, due to the small differences on investments per scenario, we used the values of the case for which we obtain the maximum profits for our analysis, the baseline case.

\section{Conclusion and Discussion}

The Belgian power sector currently finds itself in a state of uncertainty regarding the nuclear phase-out. Until now, the government's official position has been that the remaining four nuclear reactors will be shut down in 2022-2025 without license extension. However, seeing that a permit extension was granted for the oldest reactors in 2015 and taking into account the shortage of electricity supply, opinions are divided about whether or not the current permits should be extended, creating an uncertain investment climate.

In this context, the goal of our study was to analyze how, for the Belgian electricity market, uncertainty about nuclear phase-out, coupled with the implementation of renewable (RE) subsidies and nuclear taxes, affects investment capacity and productivity decisions by electricity suppliers.

A Stackelberg-based equilibrium model was developed that allows to consider the power market characteristics of the Belgian electricity suppliers, that is a leader firm that takes decisions first, and a follower firm (remaining small firms), that take decisions subsequently. Moreover, suppliers' decisions are 
chosen through a two-stage model in which, in a first stage, expansion capacities are decided under uncertainty about the extension of nuclear license permits, that is, under different probabilities of nuclear license extension. Subsequently, expansion capacities are injected in the second stage of the model and the annual number of production hours are decided in a certainty environment..

Our analysis indicates that, regardless of subsidies, an increase in the probability of extending the nuclear licenses results in lower levels of investment - primarily in renewable energy -, lower levels of total production and a higher electricity price. In absence of renewable subsidies and nuclear taxes, this increase in probability leads to a slightly decrease in total expected profits, due to the decrease in total production. However, we show that the implementation of renewable subsidies and nuclear taxes reduces the effect of the increase in probability, on total expansion capacity decisions, and total profits.

Moreover, the results show that, in the framework of decarbonization of the energy sector, there should be continued support for renewable energy in the form of subsidies, as these help to secure supply and diversify the energy mix. Indeed, RE subsidies promote new investments in renewable technologies.

Finally, our study derives relevant policy implications regarding the debate on nuclear energy. While the Belgian government currently seems committed to a nuclear phase-out, as is the case in many other European countries (Golombek et al., 2015), the biggest policital party since the 2014 Belgian parliament elections is questioning the phase-out, and most scientific reports recommend extending the nuclear license in order to reduce the current pressure on supply uncertainty, on the condition that the safety of the plants can be ensured (D’haeseleer et al., 2007; Febeliec, 2017; Groep GEMIX, 2009; International Energy Agency, 2016). Related to the safety issue but from the point of view of the individual user, Welsch and Biermann (2014) used survey data for 139517 individuals in 21 European countries and found that preferences, in terms of subjective well-being, for solar \& wind power over nuclear power have risen drastically after the Fukushima nuclear accident. In this study, we show that, in the absence of uncertainty about future nuclear energy production, i.e. when nuclear license extension or nuclear phase-out is guaranteed, the demand for electricity can be fulfilled by investing in renewable energy. In particular, in the 
case of permit extensions, results show that electricity prices will be around $9.3 \%$ higher, and there will be around $27 \%$ less investment in additional RE capacity as compared to the case of total absence of nuclear production. Moreover, these installations will be necessary in the future in order to fulfill demand. Therefore, extending the nuclear license would only postpone the problem of security of supply. A longterm energy strategy without uncertainty regarding nuclear phase-out and taking into account the future environmental benefits of RE technologies becomes necessary in order to ensure a stable investment climate.

There are possible extensions of our paper. First of all, we could improve our static model by using a multiperiod dynamic model in order to analyze the effect of uncertainty about nuclear phase-out on the evolution of investment capacity decisions over time. Also, a more complex demand-price function could be considered in the modeling - for example a constant elasticity demand function. We make the implicit assumption that electricity demand is the same throughout the year. However, demand is usually higher at night time as compared to day time, and in winter as compared to summer. This can be incorporated in the model by splitting the year into different periods, and estimating different demand price functions for each of these periods. Moreover, we could also analyze the results for an endogenously determined probability as compared to a exogenously determined and fixed probability in the current model. Finally, we made the assumption that Belgian electricity supply equals Belgian demand. In reality, however, Belgium imports a net amount of electricity from abroad. In 2014, this net import amounted to $17508 \mathrm{GWh}$ from France, the Netherlands and Luxembourg (ENTSO-E, 2016). An alternative to increasing local generation capacity is to increase the transmission capacity from neighboring countries. In order to incorporate this aspect in our model, we could consider neighboring countries as additional players in the Belgian electricity market in a third decision stage, which could strategically influence local suppliers' decisions. 


\section{Annexes}

\section{Annex 1: Profit per player per scenario}

\begin{tabular}{|c|c|r|r|}
\hline $\begin{array}{c}\text { profit } \\
\text { (million euro) }\end{array}$ & probability & Leader & Follower \\
\hline \multirow{4}{*}{$\begin{array}{c}\text { RE subsidies and } \\
\text { nuclear taxes }\end{array}$} & $\boldsymbol{\gamma}=\mathbf{1}$ & 1701 & 1953 \\
\cline { 2 - 4 } & $\boldsymbol{\gamma}=\mathbf{0 . 7 5}$ & 1693 & 1950 \\
\cline { 2 - 4 } & $\boldsymbol{\gamma}=\mathbf{0 . 5}$ & 1680 & 1945 \\
\cline { 2 - 4 } & $\boldsymbol{\gamma}=\mathbf{0 . 2 5}$ & 1662 & 1939 \\
\hline \multirow{4}{*}{$\begin{array}{c}\text { No RE subsidies } \\
\text { and no nuclear } \\
\text { taxes }\end{array}$} & $\boldsymbol{\gamma}=\mathbf{0}$ & 1756 & 1895 \\
\cline { 2 - 4 } & $\boldsymbol{\gamma}=\mathbf{0 . 7 5}$ & 996 & 294 \\
\cline { 2 - 4 } & $\boldsymbol{\gamma}=\mathbf{0 . 5}$ & 1000 & 295 \\
\cline { 2 - 4 } & $\boldsymbol{\gamma}=\mathbf{0 . 2 5}$ & 1000 & 295 \\
\hline
\end{tabular}




\section{Annex 2: Expansion in capacity per technology and player in MW}

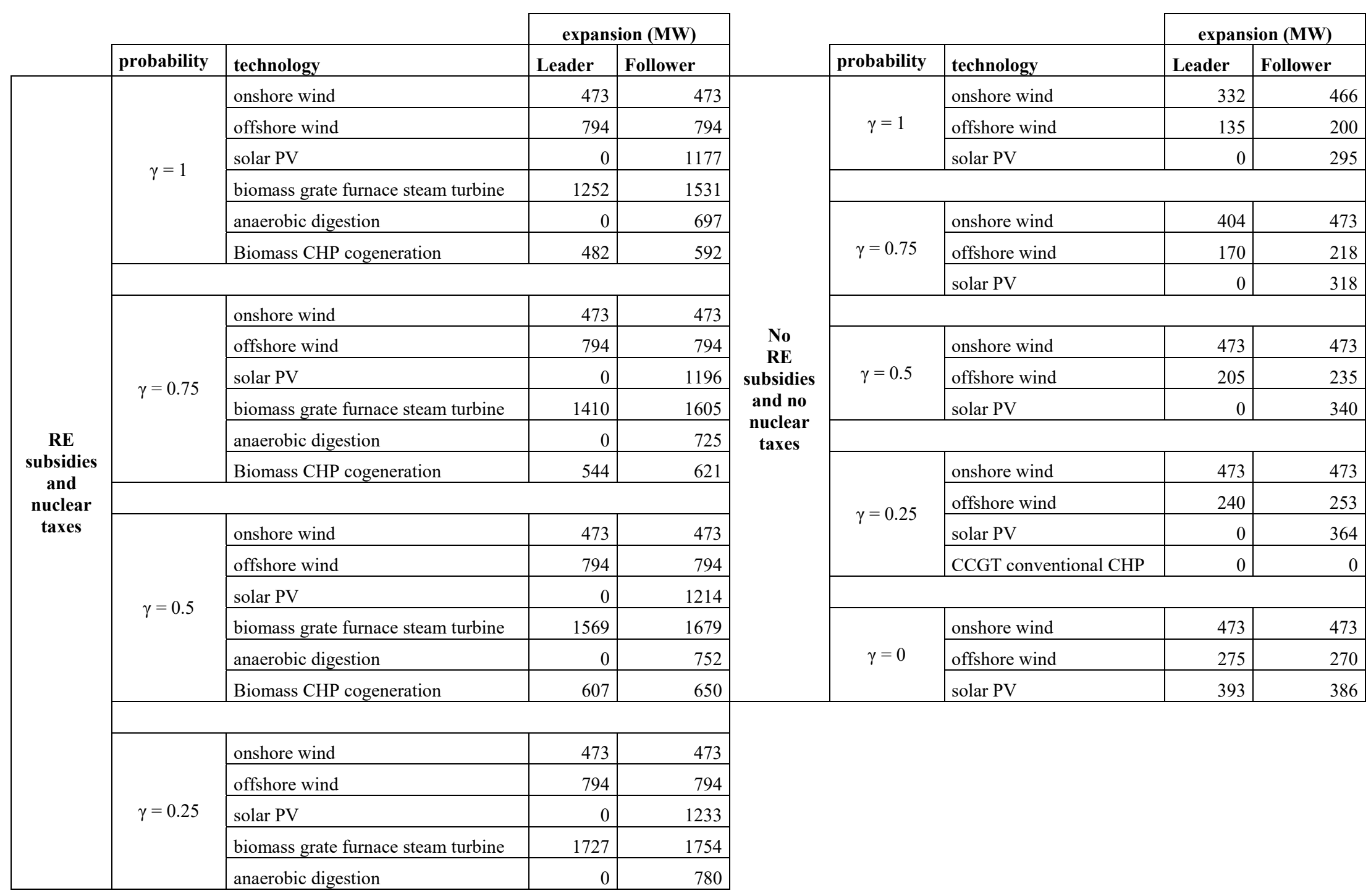




\begin{tabular}{|c|c|c|c|}
\hline & Biomass CHP cogeneration & 669 & 679 \\
\hline \multirow{6}{*}{$\gamma=0$} & onshore wind & 473 & 473 \\
\hline & offshore wind & 794 & 794 \\
\hline & solar PV & 0 & 1247 \\
\hline & biomass grate furnace steam turbine & 1853 & 1812 \\
\hline & anaerobic digestion & 817 & 802 \\
\hline & Biomass CHP cogeneration & 718 & 703 \\
\hline
\end{tabular}


Annex 3: Total expansion per technology

\begin{tabular}{|c|c|c|c|c|c|c|c|}
\hline total expansion (MW) & probability & $\begin{array}{l}\text { onshore } \\
\text { wind }\end{array}$ & offshore wind & solar PV & $\begin{array}{c}\text { biomass grate } \\
\text { furnace steam } \\
\text { turbine }\end{array}$ & $\begin{array}{l}\text { anaerobic } \\
\text { digestion }\end{array}$ & $\begin{array}{l}\text { biomass CHP } \\
\text { cogeneration }\end{array}$ \\
\hline \multirow{5}{*}{$\begin{array}{l}\text { RE subsidies and } \\
\text { nuclear taxes }\end{array}$} & $\gamma=1$ & 947 & 1588 & 1177 & 2782 & 697 & 1073 \\
\hline & $\gamma=0.75$ & 947 & 1588 & 1196 & 3015 & 725 & 1165 \\
\hline & $\gamma=0.5$ & 947 & 1588 & 1214 & 3248 & 752 & 1257 \\
\hline & $\gamma=0.25$ & 947 & 1588 & 1233 & 3481 & 780 & 1348 \\
\hline & $\gamma=\mathbf{0}$ & 947 & 1588 & 1247 & 3665 & 1619 & 1421 \\
\hline \multirow{5}{*}{$\begin{array}{l}\text { No RE subsidies and } \\
\text { no nuclear taxes }\end{array}$} & $\gamma=1$ & 799 & 336 & 295 & & & \\
\hline & $\gamma=0.75$ & 877 & 388 & 318 & & & \\
\hline & $\gamma=0.5$ & 947 & 440 & 340 & & & \\
\hline & $\gamma=0.25$ & 947 & 493 & 364 & & & \\
\hline & $\gamma=0$ & 947 & 545 & 779 & & & \\
\hline
\end{tabular}


Annex 4: Total expansion per player

\begin{tabular}{|c|c|c|c|}
\hline total expansion (MW) & probability & Leader & Follower \\
\hline \multirow{4}{*}{$\begin{array}{c}\text { RE subsidies and } \\
\text { nuclear taxes }\end{array}$} & $\boldsymbol{\gamma}=\mathbf{1}$ & 3000 & 5263 \\
\cline { 2 - 4 } & $\boldsymbol{\gamma}=\mathbf{0 . 7 5}$ & 3221 & 5413 \\
\cline { 2 - 4 } & $\boldsymbol{\gamma}=\mathbf{0 . 5}$ & 3442 & 5563 \\
\cline { 2 - 4 } & $\boldsymbol{\gamma}=\mathbf{0 . 2 5}$ & 3663 & 5713 \\
\hline \multirow{4}{*}{$\begin{array}{c}\text { No RE subsidies and } \\
\text { no nuclear taxes }\end{array}$} & $\boldsymbol{\gamma}=\mathbf{0}$ & 4655 & 5831 \\
\cline { 2 - 4 } & $\boldsymbol{\gamma}=\mathbf{1}$ & 467 & 962 \\
\cline { 2 - 4 } & $\boldsymbol{\gamma}=\mathbf{0 . 5}$ & 574 & 1009 \\
\cline { 2 - 4 } & $\boldsymbol{\gamma}=\mathbf{0 . 2 5}$ & 714 & 1089 \\
\cline { 2 - 4 } & $\boldsymbol{\gamma}=\mathbf{0}$ & 1141 & 1129 \\
\hline
\end{tabular}


Annex 5: Final installed capacity per player and technology

\begin{tabular}{|c|c|c|c|c|c|c|c|c|c|}
\hline $\begin{array}{c}\text { Final } \\
\text { installed } \\
\text { capacity } \\
(\mathrm{MW}) \\
\end{array}$ & probability & technology & Leader & Follower & $\begin{array}{c}\text { Final } \\
\text { installed } \\
\text { capacity } \\
\text { (MW) }\end{array}$ & probability & technology & Leader & Follower \\
\hline \multirow{27}{*}{$\begin{array}{c}\text { RE subsidies } \\
\text { and nuclear } \\
\text { taxes }\end{array}$} & \multirow{13}{*}{$\gamma=1$} & onshore wind & 485 & 1710 & \multirow{27}{*}{$\begin{array}{c}\text { No RE } \\
\text { subsidies } \\
\text { and no } \\
\text { nuclear } \\
\text { taxes }\end{array}$} & \multirow{13}{*}{$\gamma=1$} & onshore wind & 344 & 1703 \\
\hline & & offshore wind & 1181 & 1119 & & & offshore wind & 522 & 526 \\
\hline & & solar PV & 0 & 4130 & & & solar PV & 0 & 3248 \\
\hline & & OCGT advanced & 48 & 416 & & & OCGT advanced & 48 & 416 \\
\hline & & CCGT & 2430 & 1393 & & & CCGT & 2430 & 1393 \\
\hline & & nuclear fission generation II & 5926 & 0 & & & nuclear fission generation II & 5926 & 0 \\
\hline & & biomass furnace steam & 1615 & 1531 & & & biomass grate furnace steam turbine & 363 & 0 \\
\hline & & anaerobic digestion & 0 & 886 & & & anaerobic digestion & 0 & 189 \\
\hline & & biomass CHP cogen & 532 & 609 & & & biomass CHP cogeneration & 50 & 18 \\
\hline & & hydropower run-of-river & 12 & 74 & & & hydropower run-of-river & 12 & 74 \\
\hline & & $\begin{array}{l}\text { hydropower dam and reservoir } \\
>100 \mathrm{MW}\end{array}$ & 1164 & 144 & & & $\begin{array}{l}\text { hydropower dam and reservoir } \\
>100 \mathrm{MW}\end{array}$ & 1164 & 144 \\
\hline & & municipal solid waste incinerator & 72 & 158 & & & municipal solid waste incinerator & 72 & 158 \\
\hline & & LVN/LF & 224 & 0 & & & LVN/LF & 224 & 0 \\
\hline & \multirow{13}{*}{$\gamma=\mathbf{0 . 7 5}$} & offshore wind & 1181 & 1119 & & \multirow{13}{*}{$\gamma=0.75$} & offshore wind & 557 & 543 \\
\hline & & solar PV & 0 & 4148 & & & solar PV & 0 & 3270 \\
\hline & & OCGT advanced & 48 & 416 & & & OCGT advanced & 48 & 416 \\
\hline & & CCGT & 2430 & 1393 & & & CCGT & 2430 & 1393 \\
\hline & & pulverised supercritical coal plants & 0 & 940 & & & pulverised supercritical coal plants & 0 & 940 \\
\hline & & nuclear fission generation II & 5926 & 0 & & & nuclear fission generation II & 5926 & 0 \\
\hline & & biomass furnace steam & 1773 & 1605 & & & biomass grate furnace steam turbine & 363 & 0 \\
\hline & & anaerobic digestion & 0 & 913 & & & anaerobic digestion & 0 & 189 \\
\hline & & biomass CHP cogen & 594 & 639 & & & biomass CHP cogeneration & 50 & 18 \\
\hline & & hydropower run-of-river & 12 & 74 & & & hydropower run-of-river & 12 & 74 \\
\hline & & $\begin{array}{l}\text { hydropower dam and reservoir } \\
>100 \mathrm{MW}\end{array}$ & 1164 & 144 & & & $\begin{array}{l}\text { hydropower dam and reservoir } \\
>100 \mathrm{MW}\end{array}$ & 1164 & 144 \\
\hline & & municipal solid waste incinerator & 72 & 158 & & & municipal solid waste incinerator & 72 & 158 \\
\hline & & LVN/LF & 224 & 0 & & & LVN/LF & 224 & 0 \\
\hline & $\gamma=0.5$ & onshore wind & 485 & 1710 & & $\gamma=0.5$ & onshore wind & 485 & 1710 \\
\hline
\end{tabular}




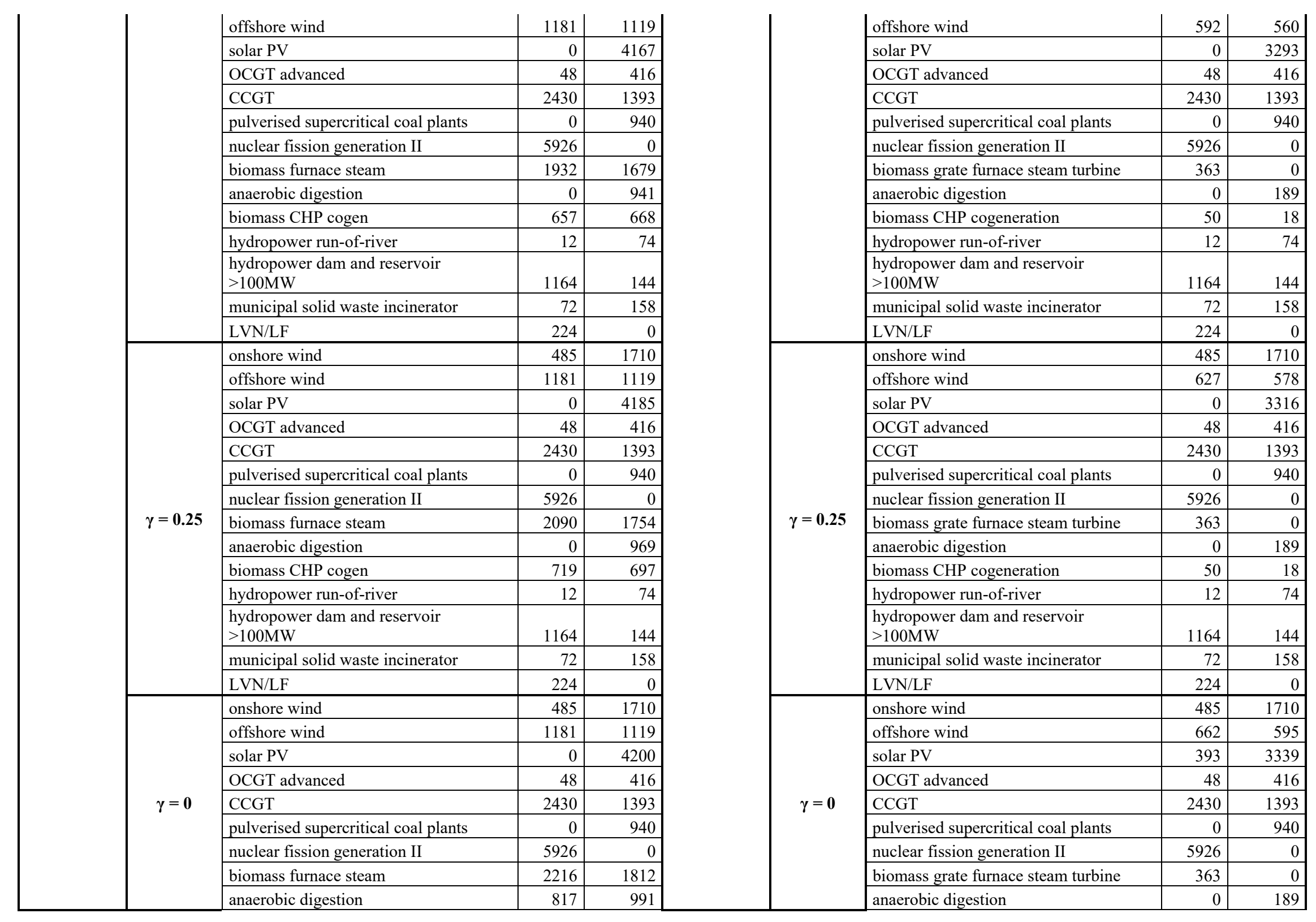




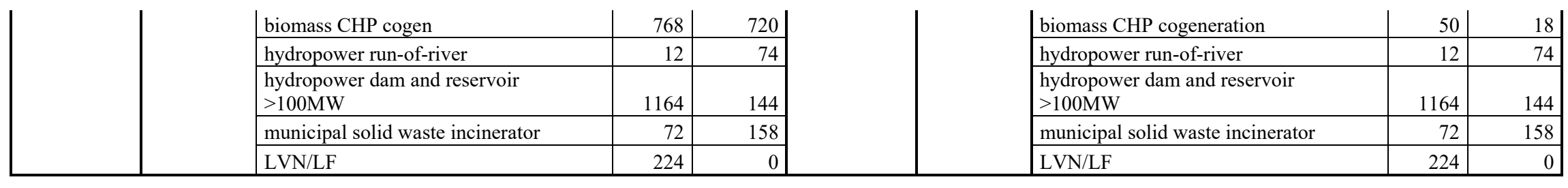


Annex 6: Quantity of producing hours per technology for all model scenarios.

\begin{tabular}{|l|r|}
\hline \multicolumn{1}{|c|}{ technology } & producing hours \\
\hline onshore wind & 2277.6 \\
\hline offshore wind & 2715.6 \\
\hline solar PV & 1007.4 \\
\hline Pulverised supercritical coal plants & 7008 \\
\hline nuclear fission generation II & 7884 \\
\hline biomass grate furnace steam turbine & 5956.8 \\
\hline anaerobic digestion & 5956.8 \\
\hline Biomass CHP cogeneration & 5956.8 \\
\hline CCGT conventional CHP & 5956.8 \\
\hline CCGT advanced CHP & 5956.8 \\
\hline hydropower run-of-river & 2978.4 \\
\hline hydropower dam and reservoir $>100 \mathrm{MW}$ & 2978.4 \\
\hline Municipal solid waste incinerator & 5956.8 \\
\hline
\end{tabular}




\section{Annex 7: Levelized Cost of Electricity (LCOE) per technology and per model scenario}

\begin{tabular}{|c|c|c|c|c|c|c|c|c|c|c|}
\hline \multirow{2}{*}{\begin{tabular}{|l} 
LCOE (euro.MWh \\
technology
\end{tabular}} & \multicolumn{5}{|c|}{ RE subsidies and nuclear taxes } & \multicolumn{5}{|c|}{ No RE subsidies and no nuclear taxes } \\
\hline & $\gamma=1$ & $\gamma=0.75$ & $\gamma=0.5$ & $\gamma=0.25$ & $\gamma=\mathbf{0}$ & $\gamma=1$ & $\gamma=\mathbf{0 . 7 5}$ & $\gamma=0.5$ & $\gamma=0.25$ & $\gamma=\mathbf{0}$ \\
\hline onshore wind & 3.97 & 3.97 & 3.97 & 3.97 & 3.97 & 3.29 & 3.63 & 3.97 & 3.97 & 3.97 \\
\hline offshore wind & 19.87 & 19.87 & 19.87 & 19.87 & 19.87 & 4.15 & 4.58 & 5.06 & 5.59 & 6.14 \\
\hline solar PV & 8.99 & 9.21 & 9.43 & 9.66 & 9.84 & 1.48 & 1.58 & 1.68 & 1.8 & 2.8 \\
\hline OCGT advanced & NA & NA & NA & NA & NA & NA & NA & NA & NA & NA \\
\hline CCGT & NA & NA & NA & NA & NA & NA & NA & NA & NA & NA \\
\hline pulverised supercritical lignine plants & NA & NA & NA & NA & NA & NA & NA & NA & NA & 76.67 \\
\hline nuclear fission generation II & 21.35 & 21.35 & 21.35 & 21.35 & 21.35 & 16 & 16 & 16 & 16 & 16 \\
\hline biomass grate furnace steam turbine & 94.11 & 95.42 & 96.77 & 98.15 & 99.26 & 79.03 & 79.03 & 79.03 & 79.03 & 79.03 \\
\hline anaerobic digestion & 78.36 & 78.79 & 79.23 & 79.66 & 81.24 & 69.44 & 69.44 & 69.44 & 69.44 & 69.44 \\
\hline biomass CHP cogeneration & 86.86 & 87.52 & 88.2 & 88.9 & 89.45 & 79.01 & 79.01 & 79.01 & 79.01 & 79.01 \\
\hline CCGT conventional CHP & 52.4 & 52.4 & 52.4 & NA & 52.4 & NA & 52.4 & 52.4 & 163.89 & NA \\
\hline CCGT advanced CHP & 54 & 54 & 54 & NA & 54 & NA & 54 & 54 & 54 & NA \\
\hline hydropower dam and reservoir $>100 \mathrm{MW}$ & 3.37 & 3.37 & 3.37 & 3.37 & 3.37 & 3.37 & 3.37 & 3.37 & 3.37 & 3.37 \\
\hline hydropower dam and reservoir $10-100 \mathrm{MW}$ & 5 & 5 & 5 & 5 & 5 & 5 & 5 & 5 & 5 & 5 \\
\hline hydropower dam and reservoir $<10 \mathrm{MW}$ & 5 & 5 & 5 & 5 & 5 & 5 & 5 & 5 & 5 & 5 \\
\hline municipal solid waste incinerator & 8.43 & 8.43 & 8.43 & 8.43 & 8.43 & 8.43 & 8.43 & 8.43 & 8.43 & 8.43 \\
\hline
\end{tabular}


Annex 8: Electricity production per technology and per model scenario

\begin{tabular}{|c|c|c|c|c|c|c|c|c|c|c|c|c|}
\hline $\begin{array}{l}\text { production } \\
\text { (GWh) }\end{array}$ & probability & $\begin{array}{c}\text { onshore } \\
\text { wind }\end{array}$ & $\begin{array}{l}\text { offshore } \\
\text { wind }\end{array}$ & $\begin{array}{c}\text { solar } \\
\text { PV }\end{array}$ & $\begin{array}{c}\text { pulverised } \\
\text { supercritical } \\
\text { coal plants }\end{array}$ & $\begin{array}{c}\text { nuclear } \\
\text { fission } \\
\text { generation } \\
\text { II }\end{array}$ & $\begin{array}{l}\text { biomass } \\
\text { grate } \\
\text { furnace } \\
\text { steam } \\
\text { turbine } \\
\end{array}$ & $\begin{array}{c}\text { anaerobic } \\
\text { digestion }\end{array}$ & $\begin{array}{c}\text { biomass } \\
\text { CHP } \\
\text { cogeneration }\end{array}$ & $\begin{array}{l}\text { hydropower } \\
\text { run-of-river }\end{array}$ & $\begin{array}{l}\text { hydropower } \\
\text { dam and } \\
\text { reservoir } \\
>100 \mathrm{MW}\end{array}$ & \begin{tabular}{|c|} 
municipal solid \\
waste incinerator
\end{tabular} \\
\hline \multirow{5}{*}{$\begin{array}{c}\text { RE } \\
\text { subsidies } \\
\text { and } \\
\text { nuclear } \\
\text { taxes }\end{array}$} & $\gamma=1$ & 5000 & 6246 & 4160 & 6588 & 46719 & 18735 & 5277 & 6798 & 256 & 3896 & 1367 \\
\hline & $\gamma=\mathbf{0 . 7 5}$ & 5000 & 6246 & 4179 & 6588 & 46719 & 20122 & 5441 & 7344 & 256 & 3896 & 1367 \\
\hline & $\gamma=0.5$ & 5000 & 6246 & 4198 & 6588 & 46719 & 21509 & 5606 & 7890 & 256 & 3896 & 1367 \\
\hline & $\gamma=\mathbf{0 . 2 5}$ & 5000 & 6246 & 4216 & 6588 & 46719 & 22897 & 5771 & 8436 & 256 & 3896 & 1367 \\
\hline & $\gamma=\mathbf{0}$ & 5000 & 6246 & 4231 & 6588 & 46719 & 23995 & 10768 & 8868 & 256 & 3896 & 1367 \\
\hline \multirow{5}{*}{$\begin{array}{l}\text { no RE } \\
\text { subsidies } \\
\text { and no } \\
\text { nuclear } \\
\text { taxes }\end{array}$} & $\gamma=1$ & 4663 & 2845 & 3272 & 6588 & 46719 & 2162 & 1125 & 404 & 256 & 3896 & 1367 \\
\hline & $\gamma=\mathbf{0 . 7 5}$ & 4842 & 2988 & 3295 & 6588 & 46719 & 2162 & 1125 & 404 & 256 & 3896 & 1367 \\
\hline & $\gamma=0.5$ & 5000 & 3130 & 3318 & 6588 & 46719 & 2162 & 1125 & 404 & 256 & 3896 & 1367 \\
\hline & $\gamma=\mathbf{0 . 2 5}$ & 5000 & 3273 & 3341 & 6588 & 46719 & 2162 & 1125 & 404 & 256 & 3896 & 1367 \\
\hline & $\gamma=\mathbf{0}$ & 5000 & 3414 & 3759 & 6588 & 46719 & 2162 & 1125 & 404 & 256 & 3896 & 1367 \\
\hline
\end{tabular}




\section{References}

Albrecht, J., Laleman, R., 2014a. Policy Trade-offs for the Belgian Electricity System, Report. Available: http://www.ceem.ugent.be/publications/Online Versie Belgian Case Study (2).pdf.

Albrecht, J., Laleman, R., 2014b. Policy Trade-offs for the Belgian Electricity System, Report. Available: http://www.ceem.ugent.be/publications/Online Versie Belgian Case Study (2).pdf.

Belga, 2017a. Bedrijven vragen tragere kernuitstap, maar botsen op kritiek: "VBO pleit voor stilstand", 30 August 2017. Available: https://www.demorgen.be/wetenschap/bedrijven-vragen-tragerekernuitstap-maar-botsen-op-kritiek-vbo-pleit-voor-stilstand-be3c0e92/.

Belga, 2017b. Nog lang geen duidelijkheid over kernuitstap, 10 October 2017. Available: https://www.demorgen.be/nieuws/nog-lang-geen-duidelijkheid-over-kernuitstap-b0b09180/.

Belgian Federal Government, 2003. Law of 31 January 2003 on the progressive exit of nuclear energy for the purpose of industrial electricity production.

Belgian Federal Government, 2002. Koninklijk besluit betreffende de instelling van mechanismen voor de bevordering van elektriciteit opgewekt uit hernieuwbare energiebronnen.

Belpex, 2016. Market data services [WWW Document]. URL https://www.belpex.be/services/marketdata-services/ (accessed 8.3.16).

Bruninx, K., Madzharov, D., Delarue, E., D’haeseleer, W., 2013. Impact of the German nuclear phase-out on Europe's electricity generation-A comprehensive study. Energy Policy 60, 251-261. https://doi.org/10.1016/j.enpol.2013.05.026

Capros, P., 1998. The PRIMES Energy System Model: summary description, National Technical University of Athens.

Centeno, E., Reneses, J., Garcia, R., Sanchez, J.J., 2003. Long-term market equilibrium modeling for generation expansion planning, in: Paper Accepted for Presentation at 2003 IEEE Bologna 
PowerTech Conference, June 23-26, Bolognam Italy. https://doi.org/10.1109/PTC.2003.1304118

Cornet, M., Duerinck, J., Laes, E., Lodewijks, P., Meynaerts, E., Pestiaux, J., Renders, N., Vermeulen, P., 2013. Scenarios for a Low Carbon Belgium by 2050.

CREG, 2010. Studie (F)100520-CDC-966 over "de verschillende ondersteuningsmechanismes voor groene stroom in België” gedaan met toepassing van artikel 23, § 2, 2, van de wet van 29 april 1999 betreffende de organisatie van de elektriciteitsmarkt.

D’haeseleer, W., Klees, P., Albrecht, J., De Ruyck, J., 2007. Commission ENERGY 2030 - Final Report Belgium's Energy Challenges Towards 2030.

Elia, 2016a. Power Generation. Available at http://www.elia.be/en/grid-data/power-generation [WWW Document]. URL http://www.elia.be/en/grid-data/power-generation (accessed 3.11.16).

Elia, 2016b. Studie over de nood aan "adequacy" en aan flexibiliteit in het Belgische elektriciteitssysteem - periode 2017-2027.

Elia, 2016c. Minimum price and legal frame green certificates [WWW Document]. URL http://www.elia.be/en/products-and-services/green-certificates/Minimumprice-legalframe (accessed 8.19.16).

ENTSO-E, 2016. Production data [WWW Document]. URL https://www.entsoe.eu/data/dataportal/production/Pages/default.aspx (accessed 8.3.16).

European Commission, 2012. Energy Roadmap 2050. https://doi.org/10.2833/10759

European Wind Energy Association, 2005. Wind Energy: the facts [WWW Document]. URL http://www.ewea.org/fileadmin/ewea_documents/documents/(accessed 3.26.16).

FANC, 2015. Flaw indications in the reactor pressure vessels of Doel 3 and Tihange 2 - Final Evaluation Report 2015. 
Febeliec, 2017. Press Release - The cost of choosing: Future electricity costs calculated for Belgium for the first time.

Filomena, T.P., Campos-Náñez, E., Duffey, M.R., 2014. Technology selection and capacity investment under uncertainty. Eur. J. Oper. Res. 232, 125-136. https://doi.org/10.1016/j.ejor.2013.07.019

Flemish Government, 2009. Decreet houdende algemene bepalingen betreffende het energiebeleid ("het Energiedecreet").

Gabriel, S.A., Leuthold, F.U., 2010. Solving discretely-constrained MPEC problems with applications in electric power markets. Energy Econ. 32, 3-14. https://doi.org/10.1016/j.eneco.2009.03.008

GAMS Development Corporation, 2010. General Algebraic Modeling System (GAMS) Release 23.6.5. Washington, DC, USA.

Genc, T.S., Sen, S., 2008. An analysis of capacity and price trajectories for the Ontario electricity market using dynamic Nash equilibrium under uncertainty. Energy Econ. 30, 173-191. https://doi.org/10.1016/j.eneco.2007.02.005

Genc, T.S., Thille, H., 2011. Investment in electricity markets with asymmetric technologies. Energy Econ. 33, 379-387. https://doi.org/10.1016/j.eneco.2010.08.004

Genc, T.S., Zaccour, G., 2011. Capacity Investments under Demand Uncertainty. Working paper.

Golombek, R., Aune, F.R., Le Tissier, H.H., 2015. Phasing out nuclear power in Europe, IAEE Energy Forum, Bergen Special 2016.

Grimm, V., Ockenfels, A., Zoettl, G., 2008. Strommarktdesign: Zur Ausgestaltung der Auktionsregeln an der EEX. Zeitschrift für Energiewirtschaft 32, 147-161. https://doi.org/10.1007/s12398-008-0020-7

Groep GEMIX, 2009. Welke is de ideale energiemix voor Belgie tegen 2020 en 2030?. Available at http://economie.fgov.be/nl/binaries/rapport_gemix_2009_nl_tcm325-201964. 
International Energy Agency, 2016. Energy policies of IEA countries: Belgium 2016 review.

International Energy Agency, 2001. Potential for Building Integrated Photovoltaics.

Joint Research Centre, 2014. Energy Technology Reference Indicator projections for 2010-2050. https://doi.org/10.2790/057687

JVH, 2016. Omstreden nucleaire heffing toch goedgekeurd. Available at http://www.demorgen.be/binnenland/omstreden-nucleaire-heffing-toch-goedgekeurd-ba30b47f/. De Morgen.

KU Leuven Energy Institute, 2015. EI Fact Sheet: The current electricity market design in Europe.

Laleman, R., Balduccio, L., Albrecht, J., 2012. The Role of Biomass in the Renewable Energy System, in: 25th International Conference on Efficiency, Cost, Optimization and Simulation of Energy Conversion Systems and Processes,. pp. 381-408. https://doi.org/10.1007/978-0-387-92740-4_1

Leibowicz, B.D., 2015. Growth and competition in renewable energy industries: Insights from an integrated assessment model with strategic firms. Energy Econ. 52, 13-25. https://doi.org/10.1016/j.eneco.2015.09.010

Liebl, D., 2013. Modeling and forecasting electricity spot prices: A functional data perspective. Ann. Appl. Stat. 7, 1562-1592. https://doi.org/10.1214/13-AOAS652

Murphy, F.H., Smeers, Y., 2005. Generation Capacity Expansion in Imperfectly Competitive Restructured Electricity Markets. Oper. Res. 53, 646-661. https://doi.org/10.1287/opre.1050.0211

Nestle, U., 2012. Does the use of nuclear power lead to lower electricity prices? An analysis of the debate in Germany with an international perspective. Energy Policy 41, 152-160. https://doi.org/10.1016/j.enpol.2011.09.043

Pauwels, L., 2016. 5 vragen over afvalverbranding en groene energie [WWW Document]. URL http://deredactie.be/cm/vrtnieuws/binnenland/1.2760219 (accessed 11.3.16). 
R Development Core Team, 2008. R: A language and environment for statistical computing. R Foundation for Statistical Computing, Vienna, Austria. ISBN 3-900051-07-0, URL http://www.R-project.org.

Schröder, A., 2014. An electricity market model with generation capacity expansion under uncertainty. Energy Syst. 5, 253-267. https://doi.org/10.1007/s12667-013-0106-0

Synatom, 2016. De repartitiebijdrage [WWW Document]. URL http://synatom.be/nl/onze-financieleactiviteiten/de-repartitiebijdrage/ (accessed 11.30.16).

Szarka, N., Scholwin, F., Trommler, M., Fabian Jacobi, H., Eichhorn, M., Ortwein, A., Thrän, D., 2013. A novel role for bioenergy: A flexible, demand-oriented power supply. Energy 61, 18-26. https://doi.org/10.1016/j.energy.2012.12.053

Van Wortswinkel, L., Lodewijks, P., 2012. Regionalisatie van Belgisch TIMES model ter uitvoering van langetermijnverkenningen voor energie en broeikasgasemissies in Vlaanderen, Report. Available: http://www.milieurapport.be/.

Ventosa, M., Baíllo, Á., Ramos, A., Rivier, M., 2005. Electricity market modeling trends. Energy Policy 33, 897-913. https://doi.org/10.1016/j.enpol.2003.10.013

Ventosa, M.J., Denis, R., Redondo, C., 2002. Expansion planning in electricity markets. Two different approaches. Proc. 14th PSCC Conf. 24-28.

Vlaams Energieagentschap, 2017. Rapport 2016 Deel 1 : Rapport OT / Bf voor projecten met een startdatum vanaf 1 januari 2017.

VREG, n.d. Minimumsteun certificaten [WWW Document]. URL http://www.vreg.be/n1/minimumsteuncertificaten\#

Welsch, H., Biermann, P., 2014. Electricity supply preferences in Europe: Evidence from subjective wellbeing data. Resour. Energy Econ. 38, 38-60. https://doi.org/10.1016/j.reseneeco.2014.05.003

Wogrin, S., Hobbs, B.F., Ralph, D., Centeno, E., Barquín, J., 2013. Open versus closed loop capacity 
equilibria in electricity markets under perfect and oligopolistic competition. Math. Program. 140, 295-322. https://doi.org/10.1007/s10107-013-0696-2

World Nuclear Association, 2016. Nuclear power in Belgium [WWW Document]. URL http://www.world-nuclear.org/information-library/country-profiles/countries-a-f/belgium.aspx (accessed 11.29.16). 


\section{Tables}

Table 1: Overview of Belgium's existing power generation structure (Elia, 2016a)

\begin{tabular}{|c|c|c|c|}
\hline Technology & $\begin{array}{l}\text { Installed capacity per } \\
\text { technology (MW) }\end{array}$ & Suppliers & $\begin{array}{l}\text { Installed capacity per } \\
\text { supplier (MW) }\end{array}$ \\
\hline Nuclear fission & $5926(30.7 \%)$ & Axpo trading & $119(0.6 \%)$ \\
\hline Coal & $1164(6.0 \%)$ & EDF Luminus & $820(4.2 \%)$ \\
\hline OCGT & $464(2.4 \%)$ & Engie Electrabel & $11339(58.8 \%)$ \\
\hline CCGT & $4588(23.8 \%)$ & $\begin{array}{l}\text { Electrawinds } \\
\text { Distributie }\end{array}$ & $38(0.2 \%)$ \\
\hline $\begin{array}{l}\text { Biomass (furnace and } \\
\text { anaerobic digestion) }\end{array}$ & $620(3.2 \%)$ & Eneco Energy Trade & $270(1.4 \%)$ \\
\hline Hydropower & $1394(7.2 \%)$ & Enel Trade & $405(2.1 \%)$ \\
\hline Solar PV & $2953(15.3 \%)$ & GETEC Energie & $556(2.9 \%)$ \\
\hline $\begin{array}{l}\text { Wind (onshore and } \\
\text { offshore) }\end{array}$ & $1961(10.2 \%)$ & Lampiris & $243(1.3 \%)$ \\
\hline \multirow[t]{6}{*}{ Waste incineration } & \multirow[t]{6}{*}{$230(1.2 \%)$} & $\begin{array}{l}\text { RWE Supply \& } \\
\text { Trading }\end{array}$ & $305(1.6 \%)$ \\
\hline & & T-Power & $422(2.2 \%)$ \\
\hline & & $\begin{array}{l}\text { Uniper Global } \\
\text { Commodities }\end{array}$ & $556(2.9 \%)$ \\
\hline & & Other ${ }^{10}$ & $4227(21.9 \%)$ \\
\hline & & Total Leader & $11339(58.8 \%)$ \\
\hline & & Total Follower & $7961(41.2 \%)$ \\
\hline
\end{tabular}

10 'Other' in this case is actually the grouping together of different renewable energy technologies which are not exploited solely by one producer but operated by SME's and households. These technologies are onshore and offshore wind energy, solar PV and anaerobic digestion. 
Table 2: Economic parameter values (left-hand side) and maximum values assumed for decision variables (right-hand side), per firm i and technology $k$

\begin{tabular}{|c|c|c|c|c|c|c|c|}
\hline $\begin{array}{l}\text { Technology } \\
\text { k }\end{array}$ & $\begin{array}{l}I_{i}^{1}(k) \\
\text { (in } \\
\text { MW) }\end{array}$ & $\begin{array}{l}C C(k) \text { (in } \\
10^{3} \\
\left.\epsilon / \mathbf{M W}^{2}\right)^{+++}\end{array}$ & $\begin{array}{l}F C(k) \\
\left(\text { in } 10^{3}\right. \\
\epsilon / \mathbf{M W})^{+++}\end{array}$ & $\begin{array}{l}V C(k) \text { (in } \\
\epsilon / M W h)^{+++}\end{array}$ & $\begin{array}{l}F S C(k) \\
\text { (in } \\
€ / \mathbf{M W h})^{+++}\end{array}$ & $\begin{array}{l}\text { Maximum } \\
P h_{\text {max }}(k) \\
\text { (in } \\
\text { hours/year) }\end{array}$ & $\begin{array}{l}\text { Maximum } \\
E_{\max }(k) \text { (in } \\
\text { MW) }\end{array}$ \\
\hline $\begin{array}{l}\text { Offshore } \\
\text { wind }\end{array}$ & 1249 & 3470 & 37.8 & 0 & 0 & 2716 & $1588^{+}$ \\
\hline $\begin{array}{l}\text { Onshore } \\
\text { wind }\end{array}$ & 712 & 1400 & 128.4 & 0 & 0 & 2278 & $947^{* *}$ \\
\hline Solar PV & 2953 & 980 & 16.7 & 0 & 0 & 1007 & $5142^{++}$ \\
\hline $\begin{array}{l}\text { OCGT } \\
\text { advanced }\end{array}$ & 464 & 550 & 16.5 & 11 & 65 & 964 & $\mathrm{n} / \mathrm{a}$ \\
\hline CCGT & 3823 & 850 & 21.3 & 2 & 50 & 7884 & $\mathrm{n} / \mathrm{a}$ \\
\hline $\begin{array}{l}\text { Pulverized } \\
\text { supercritical } \\
\text { coal plants }\end{array}$ & 940 & 1600 & 40 & 3.6 & 30 & 7008 & $0^{+}$ \\
\hline $\begin{array}{l}\text { Nuclear } \\
\text { fission } \\
\text { generation II }\end{array}$ & 5926 & 0 & 0 & 8 & 8 & 7884 & $0^{\S}$ \\
\hline $\begin{array}{l}\text { Biomass } \\
\text { grate } \\
\text { furnace } \\
\text { steam } \\
\text { turbine }\end{array}$ & 363 & 2890 & 63.3 & 3.5 & 75 & 5957 & $\mathrm{n} / \mathrm{a}$ \\
\hline $\begin{array}{l}\text { Anaerobic } \\
\text { digestion }\end{array}$ & 189 & 3880 & 159.1 & 3.1 & 65 & 5957 & $\mathrm{n} / \mathrm{a}$ \\
\hline $\begin{array}{l}\text { Biomass } \\
\text { CHP } \\
\text { cogeneration }\end{array}$ & 68 & 3670 & 84.4 & 3.3 & 75 & 5957 & $\mathrm{n} / \mathrm{a}$ \\
\hline $\begin{array}{l}\text { CCGT } \\
\text { conventional } \\
\text { CHP }\end{array}$ & 86 & 880 & 74.8 & 2.4 & 50 & 5957 & $\mathrm{n} / \mathrm{a}$ \\
\hline $\begin{array}{l}\text { CCGT } \\
\text { advanced } \\
\text { CHP }\end{array}$ & 1308 & 1010 & 39.4 & 4 & 50 & 5957 & $\mathrm{n} / \mathrm{a}$ \\
\hline $\begin{array}{l}\text { Hydropower } \\
\text { run-of-river }\end{array}$ & 230 & 5500 & 82.5 & 5 & 0 & 2978 & $0^{*}$ \\
\hline $\begin{array}{l}\text { Hydropower } \\
\text { dam and }\end{array}$ & 1249 & 2200 & 22 & 3 & 0 & 2978 & $0^{*}$ \\
\hline
\end{tabular}




\section{reservoir}

$>100 \mathrm{MW}$

Municipal

solid waste

712

6080

incinerator

*Albrecht and Laleman, 2014; **European Wind Energy Association, 2005; +Elia, 2016a; ++International Energy Agency, 2001; ${ }^{+++}$Joint Research Centre, 2014; § We assume zero expansion due to nuclear phase-out; $\S \S$ we assume that municipal solid waste incinerators are built with a main goal to get rid of waste and not to produce energy. 
Table 3: Overview of results for the different model scenarios

\begin{tabular}{|c|c|c|c|c|c|}
\hline & $\begin{array}{l}\text { Probability of } \\
\text { extending } \\
\text { nuclear } \\
\text { permits }(\gamma)\end{array}$ & $\begin{array}{l}\text { Total } \\
\text { additional } \\
\text { investment } \\
\text { capacity } \\
\sum_{i, k} E_{i}(k) \\
(\text { in } M W)\end{array}$ & $\begin{array}{l}\text { Total profit } \\
\sum_{i, k} \pi_{i}(k)(\text { in } \\
\text { million } €)\end{array}$ & $\begin{array}{l}\text { Total } \\
\text { production } \\
\sum_{i, k} Q_{i}(k) \text { (in } \\
G W h)\end{array}$ & $\begin{array}{l}\text { Electricity } \\
\text { price } p \text { (in } \\
€ / \mathbf{M W h})\end{array}$ \\
\hline \multirow{5}{*}{$\begin{array}{l}\text { RE subsidies } \\
\text { and nuclear } \\
\text { taxes }\end{array}$} & $\gamma=1$ & 8264 & 3654 & 105041 & 29.39 \\
\hline & $\gamma=0.75$ & 8635 & 3643 & 107158 & 28.98 \\
\hline & $\gamma=0.5$ & 9005 & 3626 & 109275 & 28.57 \\
\hline & $\gamma=0.25$ & 9376 & 3601 & 111392 & 28.16 \\
\hline & $\gamma=0$ & 10487 & 3650 & 117934 & 26.89 \\
\hline \multirow{5}{*}{$\begin{array}{l}\text { No } R E \\
\text { subsidies and } \\
\text { no nuclear } \\
\text { taxes }\end{array}$} & $\gamma=1$ & 1429 & 1291 & 73298 & 35.54 \\
\hline & $\gamma=0.75$ & 1583 & 1293 & 73643 & 35.47 \\
\hline & $\gamma=0.5$ & 1728 & 1296 & 73966 & 35.41 \\
\hline & $\gamma=0.25$ & 1803 & 1296 & 74132 & 35.38 \\
\hline & $\gamma=\mathbf{0}$ & 2271 & 1301 & 74691 & 35.27 \\
\hline
\end{tabular}


Table 4: Results of the different quadratic investment cost scenarios for each technology

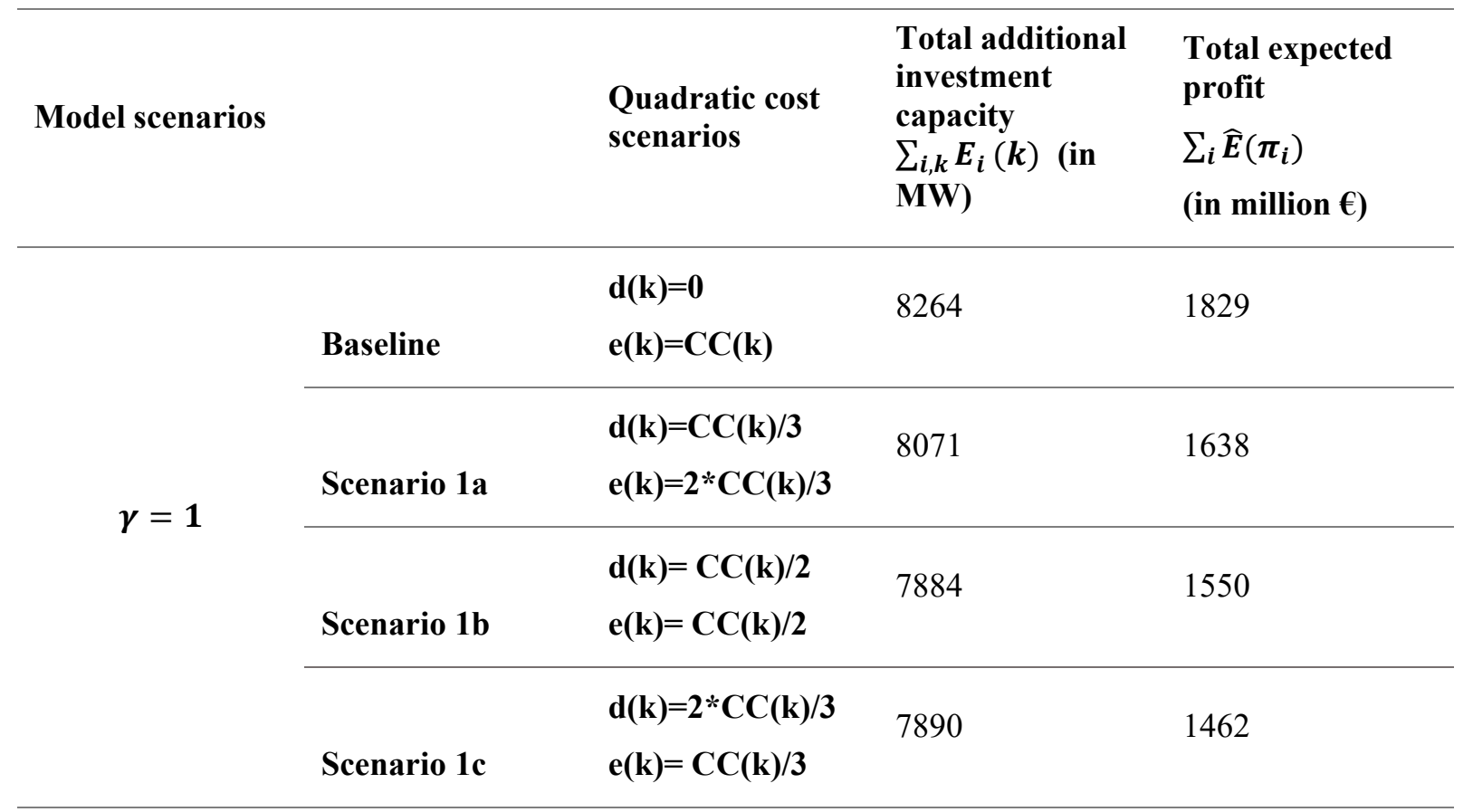




\section{Figures}

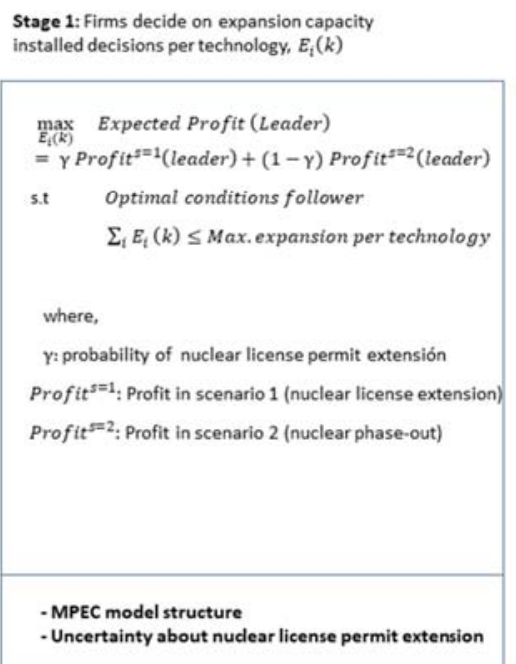

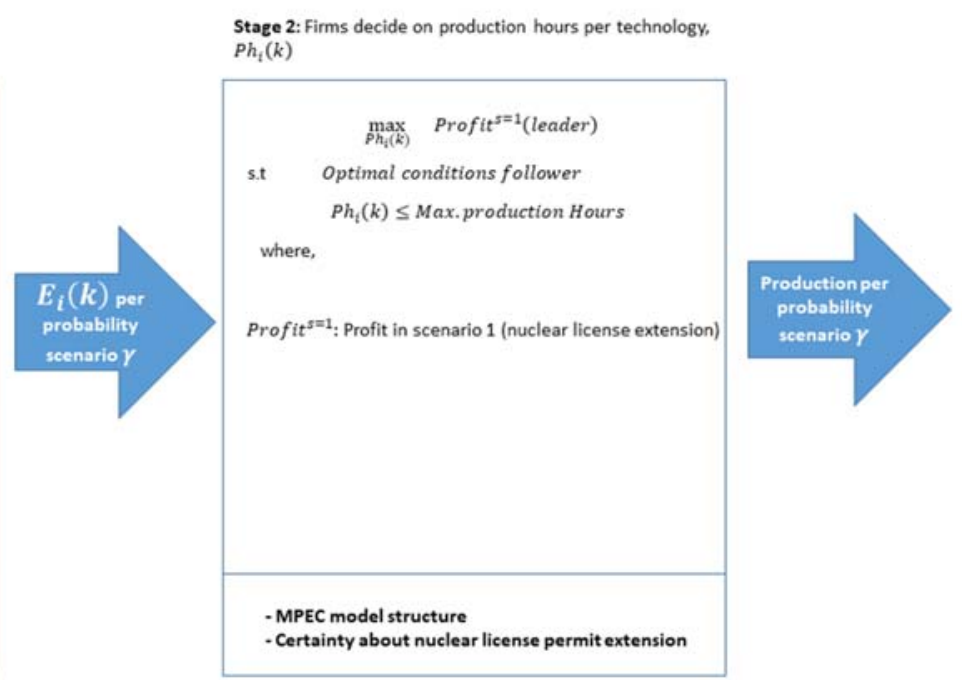

Figure 1: Decision process of the model 


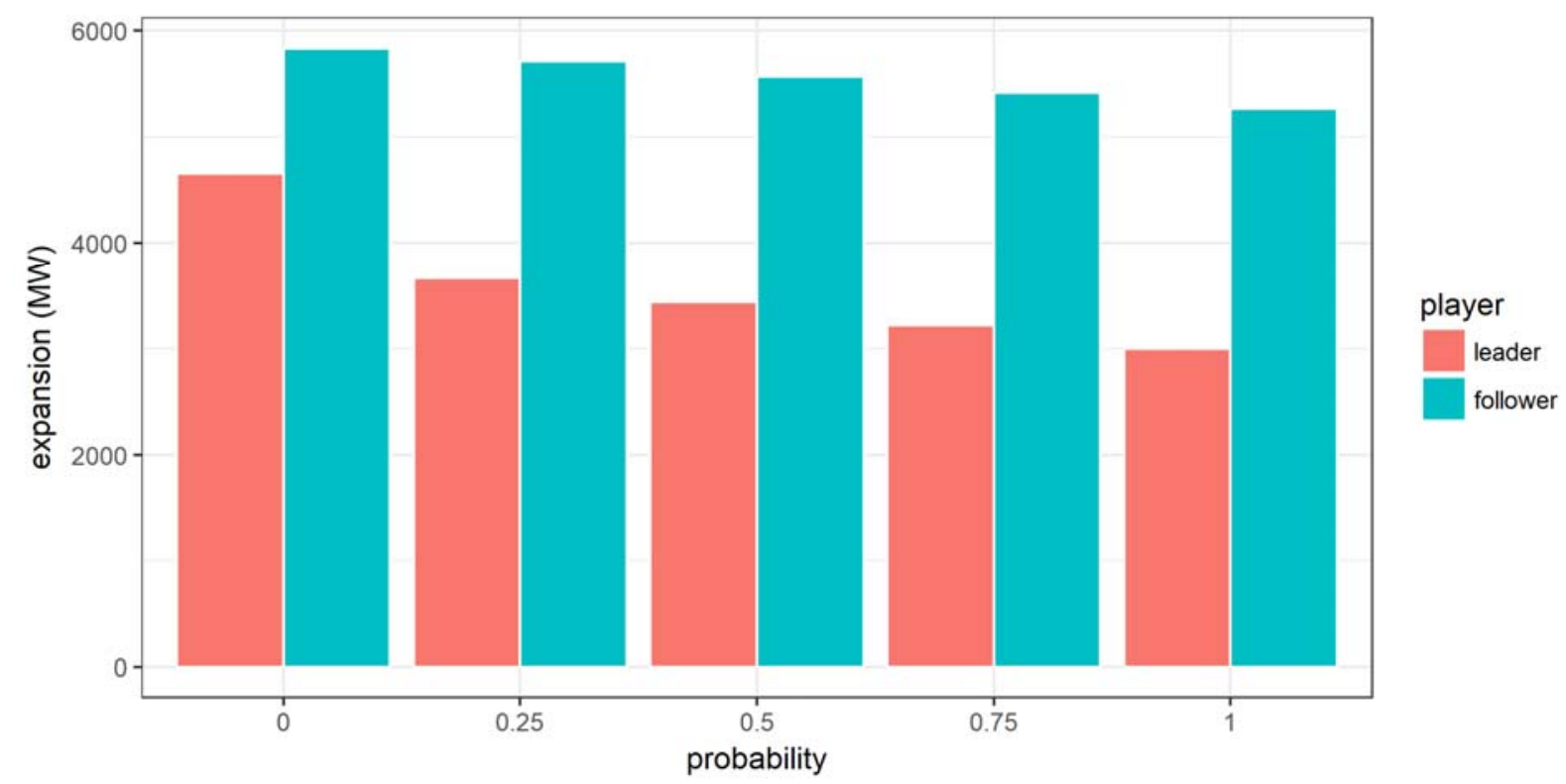

Figure 2: Expansion in capacity (in MW) in function of the level of probability of nuclear license extension $\gamma$ for the leader and follower 


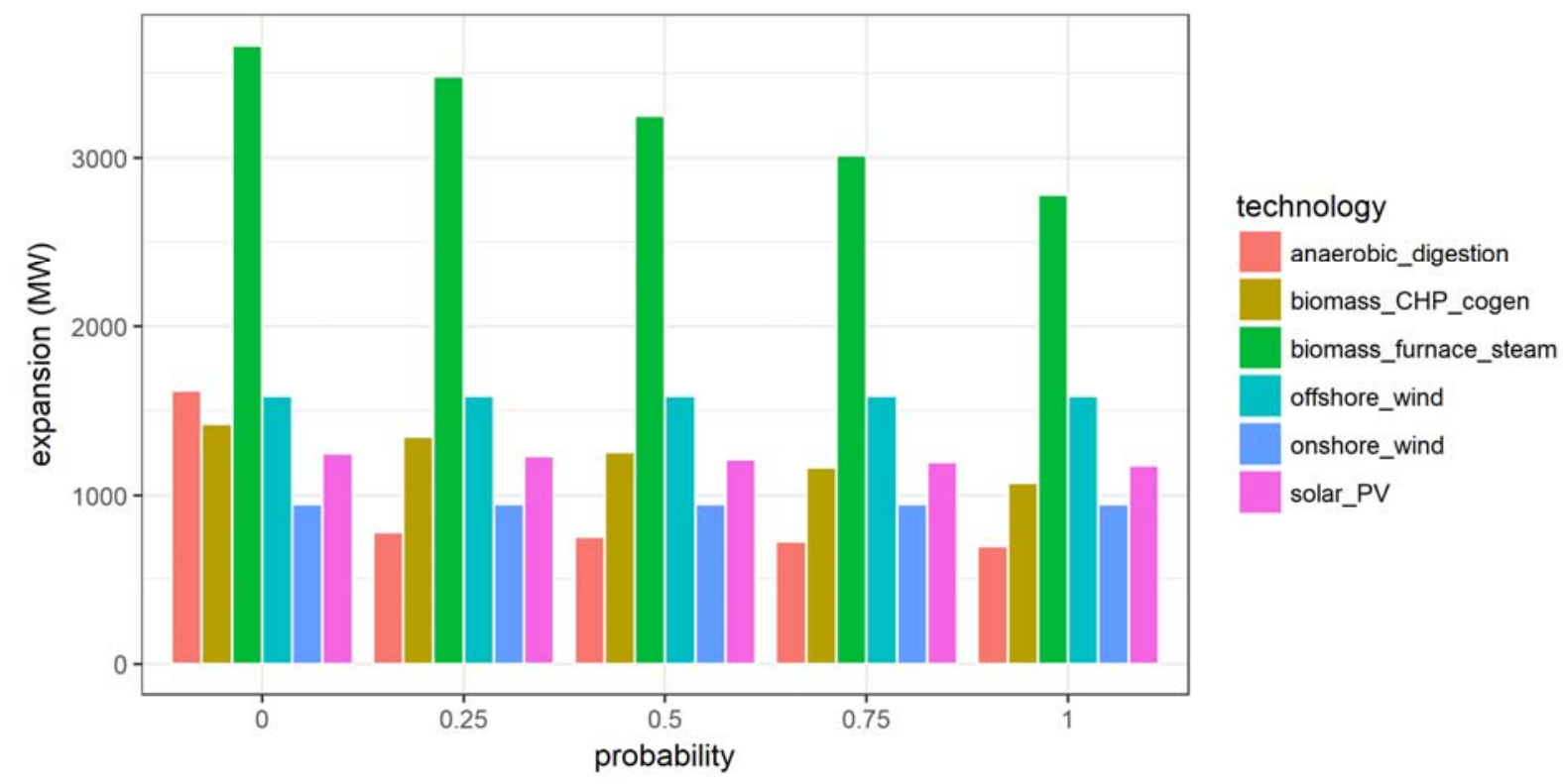

Figure 3: Installed capacity expansion (in MW) per technology and probability level $\gamma$ 


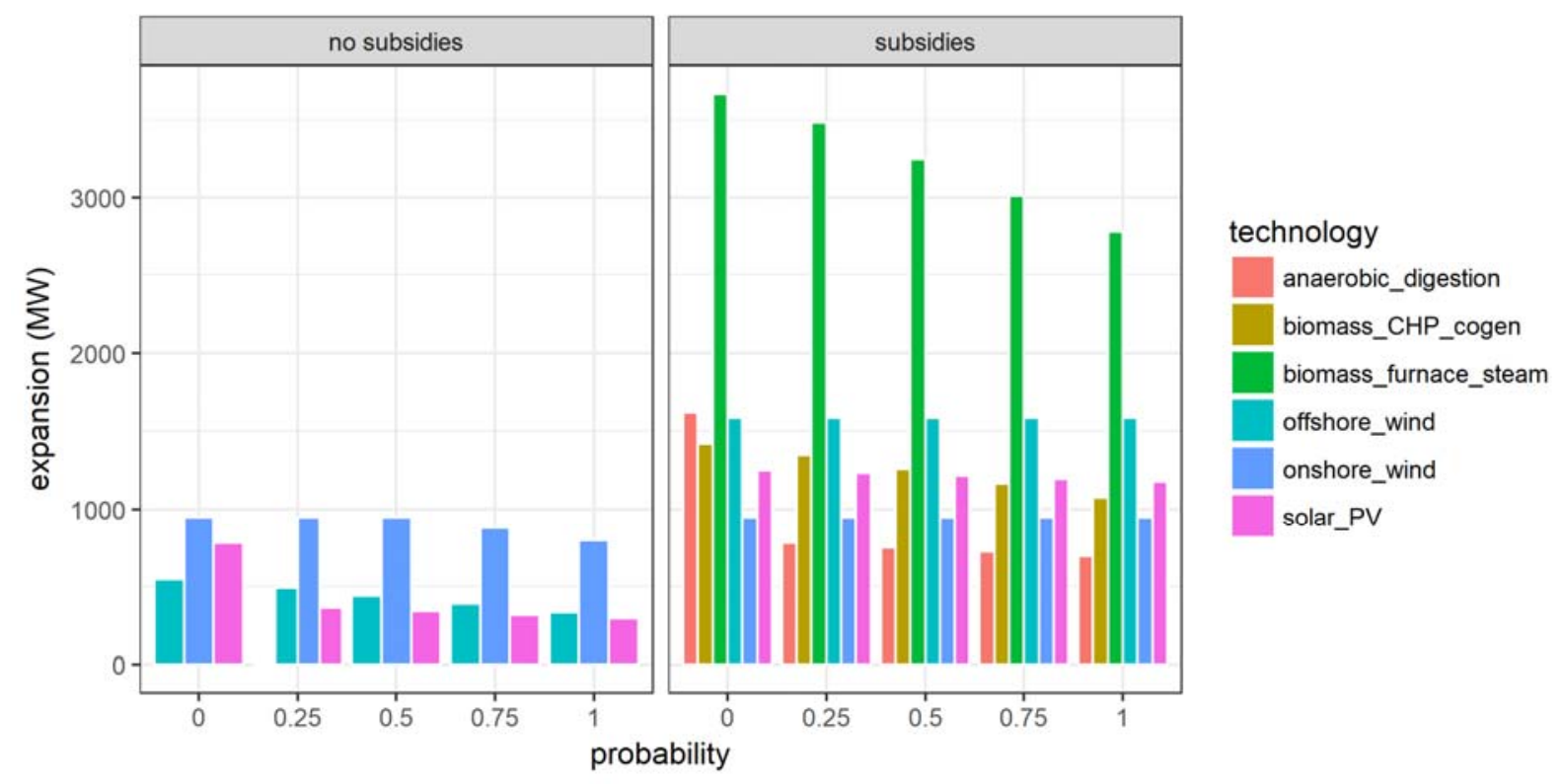

Figure 4: Expanded installed capacity per technology in absence (left-hand side) and in case (right-hand side) of RE subsidies and nuclear taxes 